\title{
Ettevõtluspädevuse mudel ettevõtlusõppe arendamise alusena
}

\author{
Urve Venesaar ${ }^{\mathrm{a}}$, Marge Täks ${ }^{\mathrm{bc}}$, Grete Arro ${ }^{\mathrm{d}}$, Elina Malleus ${ }^{\mathrm{de}}$, \\ Krista Loogma ${ }^{d}$, Kaja Mädamürk ${ }^{\mathrm{d}}$, Eneken Titov', Martin Toding ${ }^{\mathrm{a}}$ \\ a Tallinna Tehnikaülikooli ärikorralduse instituut \\ ${ }^{b}$ Tartu Ülikooli majandusteaduskond \\ ${ }^{c}$ Estonian Business School \\ d Tallinna Ülikooli haridusteaduste instituut \\ e Tallinna Ülikooli loodus- ja terviseteaduste instituut \\ ${ }^{f}$ Eesti Ettevõtluskõrgkool Mainor
}

\begin{abstract}
Annotatsioon
Artikli eesmärk on kirjeldada ja empiiriliselt põhjendada ettevõtluspädevuse mudelis sisalduvate alapädevuste valikut, et luua alus ettevõtlusõppe arendamiseks ning toetada õppijate ettevõtluspädevuse arengut ja toimetulekut nii töös (sh ettevõtluses) kui ka igapäevaelus. Ettevõtluspädevuse mudel hõlmab 14 alapädevust, mis on jaotatud enesejuhtimise, väärtust loova mõtlemise, sotsiaalsete olukordade lahendamise ja äriideede elluviimise valdkonnaks. Kõrgkooliõpilaste $(N=1479)$ hulgas tehtud uuringust ilmneb, et seosed alapädevuste vahel on ootuspärased ja vastavad teoreetilistele eeldustele. See lubab arvata, et alapädevused moodustavad terviku ning on usaldusväärseks aluseks õppija ettevõtluspädevuse arendamisele ja toetamisele. Artikkel soodustab diskussiooni ettevõtluspädevuse ja selle arendamise võimaluste üle, pakkudes ühtlasi välja lähtekoha ettevõtlusõppe arendamiseks Eesti haridussüsteemis.
\end{abstract}

Võtmesõnad: ettevõtlusõpe, ettevõtluspädevuse mudel, ettevõtlikkus, enesejuhtimine, väärtusloome, sotsiaalsed oskused

Ärikorralduse instituut, Tallinna Tehnikaülikool, Akadeemia tee 3, 12618 Tallinn; urve.venesaar@ttu.ee 


\section{Sissejuhatus}

Viimastel kümnenditel on ettevõtlusõppe valdkonna uurimustes olnud kesksel kohal soov kujundada parem arusaam ettevõtluspädevuse arendamisest (nt Bird, 1995; Cope, 2005; Man, Lau, \& Snape, 2008; Sarasvathy \& Venkataraman, 2011). Ettevõtlusõppe tähtsus on Euroopa Liidu riikides jätkuvalt kasvanud (nt European Commission, 2006, 2016; Lans, Hulsink, Baert, \& Mulder, 2008). Euroopa Parlamendi ja nõukogu soovitustes on ettevõtlikkus (sense of initiative and entrepreneurship $)^{2}$ lisatud kaheksa elukestva õppe võtmepädevuse hulka (European Commission, 2016) kui kõigile kodanikele oluline ja hädavajalik pädevus, mis võimaldab ühiskonnas hakkama saada. Näiteks on Ameerika Ühendriikides, samuti Ühendkuningriigis, Taanis jt Euroopa riikides (EL) loodud ettevõtluspädevuse mudelid (Bacigalupo, Kampylis, Punie, \& van den Brande, 2016; Gibb, 2008; National ..., 2004; Rasmussen \& Fritzner, 2016; Rasmussen, Moberg, \& Revsbech, 2015), mis aitavad luua parema arusaama ettevõtluspädevusest ja toetavad ettevõtluspädevuse arendamist elukestvas õppes.

Ettevõtluse mõiste defineerimisel juhindutakse kitsast ja viimasel ajal üha enam ka laiast käsitusest (Gibb, 2010; Lackéus, 2015). Ettevõtluse mõiste kitsa käsituse korral mõistetakse ettevõtlust kui uue ettevõtte loomist ja arendamist. Laia käsituse alusel nähakse ettevõtlust ühiskonnas väärtuse loomise igapäevase tegevusena (Blenker et al., 2012), mis võimaldab indiviidil end teostada mitte ainult ettevõtjana, vaid ka teistes ettevõtmistes (Steyaert \& Katz, 2004). Õppe kavandamine laiast käsitusest lähtudes eeldab, et õppeprotsessides toetatakse õppijate ettevõtlikkuse arenguks vajalike alapädevuste ${ }^{3}$ kujundamist. Seega on vaja pöörata senisest suuremat tähelepanu ettevõtlikkuse mõistmisele ning sellega seotud alapädevuste arengule nii ettevõtlusainetes kui ka ettevõtlusõppe lõimimisel kõigisse õppekavade sisuühikutesse, nt moodulitesse, ainetesse. Eelnevat silmas pidades võib ettevõtlusõpet vaadata kui omaette eriala (nt eraldiseisev õppeaine või õppekava) ja/või ettevõtlikkust arendavat meetodit, st võimalust lõimida ettevõtlusõpet kõigisse või enamikku õppekavade sisuühikutesse ja toetada õppija ettevõtlikkust (Blenker, Korsgaard, Neergaard, \& Thrane, 2011; Fayolle, 2013; Neck \& Greene, 2011). Ettevõtluse mõiste laia käsituse korral on ettevõtlusõppe eesmärk arendada ettevõtluspädevust kui üle-

Euroopa Komisjoni 2006. aasta dokumendis on termin sense of initiative and entrepreneurship tõlgitud eesti keelde kui algatusvõime ja ettevõtlikkus. Kuna sisuliselt märgib see termin ettevõtlikkust, on siinses artiklis jäädud ettevõtlikkuse juurde.

3 Ettevõtluspädevust vaadeldakse alapädevuste kogumina, milles võib eristada ettevõtlikkust toetavaid alapädevusi (nt enesejuhtimine, väärtust loov mõtlemine ja lahenduste leidmine, sotsiaalsed oskused) ning ettevõtlusalaseid teadmisi ja oskusi, mida kasutatakse äriideede elluviimiseks. 
kantavat (transversal) pädevust, mida saab rakendada kõigis eluvaldkondades. Kuigi lai käsitus on olnud viimasel ajal nii poliitikakujundajate kui ka teadlaste tähelepanu keskpunktis, on selle praktilise rakendamise kohta vähe empiirilist tõendusmaterjali (Lackéus, 2015).

Teadlased ja praktikud otsivad vastust küsimustele „Mida sisaldab ettevõtluspädevus?“ ja „Kuidas ettevõtluspädevuse arendamist toetada (õpetada/ õppida)?". Varasemate uurimuste põhjal on teada, et ettevõtlust õpetatakse koolides väga erinevalt (Fayolle, Gailly, \& Lassas-Clerc, 2006), sest puudub konsensus põhimõistetes ettevõtlus, ettevõte ja ettevõtja (Mwasalwiba, 2010) ja ettevõtluse õpetamise meetodites (Bennett, 2006). Selline olukord tekitab segadust ettevõtlusõppe kavandamisel (Pittaway \& Cope, 2007), õppe eesmärkide püstitamisel, õpiväljundite sõnastamisel ning õppe- ja hindamismeetodite valikul (Mwasalwiba, 2010). Paljudel juhtudel ei arvestata õppetöö kavandamisel õppijate varasemaid pädevusi, mistõttu võib ettevõtlusõpe osale õppijatest olla vana kordamine ning teistele käia üle jõu. Probleemi lahendamiseks on vaja ettevõtlusõppe kavandamisel arvestada varasemate õpingute jooksul omandatud pädevusi / teadmisi ja oskusi, samuti seda, milliseid pädevusi on õppijal kasulik arendada edasiste õpingute käigus. Samas puudub teoreetiliselt põhjendatud alus ettevõtlusõppe süsteemseks kavandamiseks kõigil haridustasemetel, mille korral võetaks arvesse nii ettevõtluse valdkonna iseärasusi kui ka õppija isiksuse arengu seaduspärasusi.

Eesti haridussüsteemis on ettevõtlusõppele suuremat tähelepanu pööratud alates 2007. aastast ning ettevõtlusõpet on pakutud pigem ettevõtlusainena, mille eesmärk on toetada õppijate ettevõtlusalaste teadmiste ja oskuste arendamist ning uute ettevõtete loomist. Hiljuti on üha olulisemaks muutunud ettevõtlusõppe laia käsituse rakendamine, st ettevõtluspädevuse ja/või selle alapädevuste läbiv lõimimine õppekavadesse, eriala- ja aineõppesse. Pädevuste lõimimisega toetatakse õppija ettevõtliku hoiaku kujundamist, sh enesejuhtimise, väärtust loova mõtlemise ja sotsiaalsete oskustega seotud pädevuste arendamist ning selleks vajaliku keskkonna loomist, kogu tema haridustee vältel (nt Karimi, Biemans, Lans, Aazami, \& Mulder, 2014; Kikas, 2015; Sarasvathy \& Venkataraman, 2011). Varem on laia käsituse rakendamine olnud keeruline seetõttu, et ettevõtlusõppe sisu ei ole olnud haridustasemeti ja -liigiti selgelt kindlaks määratud. Teisisõnu on õppe kavandamisel lähtutud eri arusaamadest või teooriatest, mis ei moodusta järjepidevat ja sidusat tervikut. Nimetatud lünga kõrvaldamiseks algatas Haridus- ja Teadusministeerium programmi „Ettevõtlikkuse ja ettevõtlusõppe süsteemne arendamine kõigil haridustasemetel“ (Edu ja Tegu ..., 2016).

Artikli eesmärk on kirjeldada ja empiiriliselt põhjendada programmi „Edu ja tegu" raames välja töötatud ettevõtluspädevuse mudelis sisalduvate ala- 
pädevuste valikut, sest see mudel loob aluse ettevõtlikkuse ja ettevõtlusõppe süsteemseks ning järjepidevaks arendamiseks Eestis. Sellest lähtudes sõnastati järgmised uurimisküsimused.

1. Mis pädevusi on tarvis, et keskkonnavõimalusi kasutades ideid ellu viia ja nende kaudu väärtusi luua?

2. Kuidas empiiriliselt põhjendada ettevõtluspädevuse mudelis sisalduvate alapädevuste valikut?

Ettevõtluspädevuse mudeli väljatöötamisel on toetutud ettevõtluse mõiste määratlusele, mille kohaselt on ettevõtlus ideede elluviimise protsess, samuti on arvesse võetud, mis pädevusi on vaja, et leida uusi ja väärtust loovaid lahendusi, et ettevõtlusprotsessi eri etappidel (äri)ideid arendada ja ellu viia. Ettevõtluspädevuse alapädevuste sisu on interdistsiplinaarne - selle kirjeldamisel toetutakse eri teadusvaldkondade, sh psühholoogia, haridusteaduste jt raames loodud teoreetilistele ja kontseptuaalsetele käsitlustele. Peale selle, et mudeli abil on kirjeldatud ettevõtluspädevust, on selle alusel koostatud ka (enese)hindamisvahend, et mõõta kognitiivse arengu seaduspärasusi. Ühtlasi saab hindamisvahendi abil kogutud andmetele tuginedes uurida ja hinnata mudeli ning alapädevuste usaldusväärsust.

Artiklis kirjeldatud ettevõtluspädevuse mudeli sisu avamine aitab selgitada põhimõtteid, mille alusel saab kavandada ettevõtlikkuse kui ülekantava pädevuse seoseid aine- ja erialaõppega üld-, kutse- ja kõrghariduses, aga ka ettevõtlusõppe süsteemset arendamist kõigi haridustasemete kaudu. Samuti pakub artikkel ainest nii ettevõtlusõppega seotud teemade mõtestamiseks (sh õpetajatele ja õppejõududele) kui ka õppe- ja ainekavade planeerimiseks.

\section{Ettevõtluspädevuse alapädevuste käsitlused ettevõtlusalastes teadusuurimustes}

Pädevuspõhist õpet peetakse hariduse ajakohastamise strateegiliseks vahendiks ning võtmeteguriks koolituste lõimimisel elukestva õppega (Haridusja Teadusministeerium, 2018; OECD, 2016). Ühtlasi arvatakse, et pädevuspõhine õpe valmistab õppijaid tööturule sisenemiseks paremini ette (European Commission, 2006; OECD, 2016). Arvestades Euroopa Komisjoni raportis toodud kitsaskohti, võib järeldada, et ettevõtlusõppe mõju suurendamiseks on vaja paremat arusaama ja süsteemsemat lähenemist ettevõtluspädevuse ja selle alapädevuste arendamisele õppija kogu haridustee vältel (European Commission, 2016).

Teaduskirjandusest leiab mitmesuguseid pädevuste määratlusi, millest hiljutisemad rõhutavad spetsiifilise tegevuse ja selle konteksti tähtsust pädevuste kirjeldamisel. Näiteks väljendab pädevus omavahel kombineeritud teadmiste, 
oskuste ja hoiakute mustreid, mis on olulised soovitud tulemuste saavutamisel eripärases kontekstis (Bartram, 2005; Wesselink \& Wals, 2011). Samuti käsitatakse pädevusena võimet tegutseda praegu ja tulevikus, võttes oma tegevuse eest vastutuse (Mulder, Gulikers, Biemans, \& Wesselink, 2009). Gibbi (2008) määratluse järgi on pädevus „käitumine, oskused ja omadused, mida saab rakendada individuaalselt ja kollektiivselt ning mis aitavad üksikisikutel ja organisatsioonidel luua, hallata, nautida muutusi ja uuendusi ebakindlas, keerukas keskkonnas, toetades personaalse ja organisatsioonilise tõhususe saavutamist" (lk 106). Taani mudelis on ettevõtluspädevust kirjeldatud kui teadmisi, oskusi, subjektiivseid suhteid ja võimalikke tegevussuundi, mis võimaldavad hakkama saada ebakindlates olukordades (Rasmussen et al., 2015), rõhutades vajadust arendada õppijate ettevõtluspädevust, sh ettevõtlikkust. Kokkuvõttes saab väita, et ülaltoodud näidetes on ettevõtluspädevuse defineerimisel fookuses ettevõtlusalased teadmised ja oskused, ettevõtlik hoiak, tegevuspõhisus ning väärtusloome komponendid ja nende kontekstisidusus.

Siinses artiklis toetutakse ettevõtluspädevuse mõiste määratlemisel ettevõtluse definitsioonile, milles vaadeldakse ettevõtlust kui protsessi, kus ettevõtluskeskkonna võimalusi kasutades viiakse ellu ideid, luues teistele väärtusi (FFE-YE, 2012). Seejuures mõistetakse väärtuse loomise all eesmärgistatud tegevust, mille tulemusena luuakse sotsiaalseid, kultuurilisi või majanduslikke väärtusi. Uurimuse teoreetiliseks lähtekohaks on ettevõtluse lai käsitus, mis hõlmab kõike alates uue ettevõtte toomisest turule või uue toote arendamisest juba tegutsevas ettevõttes kuni ettevõtliku eesmärgistatud käitumiseni igapäevategevustes (nt Blenker et al., 2011) ja sotsiaalsete probleemide lahendamiseni. Ettevõtluse definitsioonist lähtudes võib küsimuse ettevõtluspädevuse sisu kohta sõnastada järgmiselt: mis pädevusi on vaja, et viia ideid ellu ja luua nende kaudu väärtusi?

Kõige enam levinud ettevõtlusprotsessi käsitus pärineb Shane'ilt (2003), kes kirjeldab ettevõtlust kui ärivõimaluste avastamise ja kasutamise protsessi. Ideede elluviimisel võib ettevõtlusprotsess koosneda mitmest etapist, sh võimaluste avastamisest, nende hindamisest ja rakendamisest (ibid.). Lisaks on iga protsess eri pikkusega ning kulgeb mittelineaarselt (McMullen \& Dimov, 2013). Ettevõtlusprotsessi vaadeldakse kui indiviidi(de) ja võimaluste (põhjuslikku) seost, mille tulemusena luuakse organisatsioon (nt Shane \& Venkataraman, 2000). Seda ettevõtlusprotsessi määratlust on kritiseeritud ja täpsustatud mitmest aspektist, et rõhutada võimaluste ja indiviidide vahelise seose keerukust (nt Davidsson, 2015; Dimov, 2007). Ettevõtlusprotsessi keerukuse mõistmine aitab paremini aru saada ka selle sisust. Samas sobib ettevõtlusprotsessi kirjeldus (vt Shane, 2003) rakendamiseks nii ettevõtluse kitsa kui ka laia käsituse korral, sest see toetub kahele olulisele komponendile: (ettevõtlikule) indiviidile 
ja konkreetses keskkonnas avanevatele võimalustele. Seejuures avastatakse ja/ või luuakse võimalusi (vt nt Alvarez \& Barney, 2010) keskkonnas, kus ettevõtlusprotsess aset leiab. Võimaluste avastamise ja rakendamise edukus sõltub suuresti ettevõtlusprotsessis osaleva(te) indiviidi(de) isiksuslikest teguritest (Shane, 2003), ühtlasi pakub see protsess indiviididele võimalust arendada samal ajal oma teadmisi ja oskusi. Ettevõtlusprotsessi mõistmiseks on vaja teada, miks, millal ja kuidas võimalusi avastatakse või luuakse, kes ja mil viisil seda teevad ehk mis tegurid seda toetavad, sh isiku teadmised, omadused, uskumused, motivatsioon (Shane \& Venkataraman, 2000).

Seni on kõige enam uuringuid tehtud ettevõtlusprotsessi esimese, st võimaluste avastamise etapi kohta. Nende uuringute tulemused kinnitavad, et võimaluste avastamiseks läheb vaja arendatavaid spetsiifilisi pädevusi, nt loovust, probleemilahendusoskust (Baggen et al., 2018; Baron \& Ensley, 2006; DeTienne \& Chandler, 2004). Uute võimaluste avastamise võimekust nähakse ettevõtja olulise pädevusena, mis aitab saavutada edu (Ardichvili, Cardozo, \& Ray, 2003). Äriideede arendamist kui tähtsat etappi võimaluste avastamisel seostatakse loovuse ja mõtlemisoskusega (Ucbasaran, Westhead, \& Wright, 2008), mis on vajalikud nii info kasutamiseks kui ka uute lahenduste leidmiseks. Ärivõimaluste avastamise etapis on oluline osata infot otsida ja hinnata, samuti rakendada seda interaktsioonis sotsiaalse keskkonnaga (Corbett, 2005; Kyndt \& Baert, 2015). Niisama tähtsad on sügavad valdkondlikud teadmised (ibid.). Võimaluste avastamist mõjutavad ka indiviidide isiklikud eesmärgid ja motivatsioon, kusjuures motivatsiooni on seostatud pädevuste arendamise ja ettevõtte tulemuslikkusega (nt Baum \& Locke, 2004). Võimaluste avastamine ei toimu isolatsioonis, vaid see protsess eeldab osalejalt orienteerumist ettevõtluskeskkonna eri tahkudes (nt poliitilises, majanduslikus, sotsiaalses, tehnoloogilises, kultuurilises, ökoloogilises) ja eri tasanditel (nt kohalikul, riiklikul, globaalsel) ning võimet analüüsida keskkonna mõju väärtust loovatele, sh ettevõtlusalastele tegevustele (Rasmussen \& Nybye, 2013). Selleks, et teha otsuseid, mis loovad isiklikku ja ühiskondlikku rahalist heaolu, on samuti tarvilik orienteeruda rahaasjades ning mõista ressurssidega seotud materiaalseid ja mittemateriaalseid riske (OECD, 2016).

Äriideede elluviimisel tuleb suhelda meeskonnaliikmetega ning luua sotsiaalseid võrgustikke väliste partnerite ja klientidega, et hankida uut informatsiooni, ressursse või nõuandeid (Lans, Blok, \& Gulikers, 2015). Seepärast on ettevõtlusprotsessis vaja suhtlemis- ja koostööoskusi, mida toetavad sotsiaalne teadlikkus, emotsioonide reguleerimine suhtlemisel ning eneseteadlikkus ja -juhtimine ettevõtlusprotsessis vajalike otsuste tegemisel (Baron \& Markman, 2003). Ettevõtlusõppe kontekstis on rõhutatud vajadust arendada metatunnetust kui üht ettevõtlusalase edukuse eeldust (Mitchell, Smith, Gustafsson, Davidsson, \& Mitchell, 2005). 
Paljudes uurimustes vaadeldakse ettevõtlusega seotud pädevusi ettevõtlusprotsessi faasides kitsamalt, nt ettevõtlusega alustamise pädevusi ettevõtte arendamise või kasvu faasis. Ettevõtlusõppele keskendunud uurimustes on käsitletud ka kombinatsiooni pädevustest, mis on vajalikud nii ettevõtlusega alustamisel (nt Baggen et al., 2018) kui ka juba tegutsevate ettevõtete juhtimisel (Man, Lau, \& Chan, 2002). Esitatud on ka mitmeid enesehindamise vahendeid, mis võimaldavad hinnata üliõpilaste ja/või ettevõtjate teadmisi, oskusi ja hoiakuid ettevõtlusega tegelemisel (eeltoodule lisaks nt Kyndt \& Baert, 2015; Morris, Webb, Fu, \& Singhal, 2013). Kasutatud on nii psühhomeetrilisi teste üksikute alapädevuste hindamiseks kui ka kombineeritud meetodeid (Lans, Biemans, Mulder, \& Verstegen, 2010). Alapädevuste hindamise vahendid on abiks pädevuspõhise õppe rakendamisel.

Ettevõtluspädevuse mudeli väljatöötamisel saab tugineda eri põhimõtetele. Näiteks on Le Deist ja Winterton (2005) tutvustanud kolme põhimõtet: käitumuslikku, funktsionaalset ja terviklikku. Lisaks on Winterton (2002) pakkunud välja mitmedimensioonilise raamistiku nelja valdkonnaga, milleks on kognitiivne, funktsionaalne, personaalne ja metatunnetuslik valdkond. Taani (Rasmussen et al., 2015), Euroopa (Bacigalupo et al., 2016) ja Skandinaavia (Rasmussen \& Fritzner, 2016) ettevõtluspädevuse mudelid esindavad terviklikku käsitlust, võttes arvesse valdkondlikku spetsiifikat eri keskkondades väärtuse loomisel. Seejuures on pädevusmudelite kujundamisel tähtis arvestada konteksti, kus äriideid ellu viiakse (Lilleväli \& Täks, 2017). Siinses artiklis käsitletava ettevõtluspädevuse mudeli kirjeldamisel ja empiirilisel põhjendamisel lähtutakse eesmärgist luua alus ettevõtlikkuse ja ettevõtlusõppe arendamiseks Eestis kõigil haridustasemetel ja elukestvas õppes. Ettevõtluspädevuse mudeli terviklikkust tuleb hinnata selle järgi, kuivõrd mudeli alapädevuste arendamine võimaldab ideede elluviimisel luua väärtusi nii ettevõtluse mõiste kitsas kui ka laias tähenduses.

\section{Eesti ettevõtluspädevuse mudel}

Ettevõtluspädevuse definitsioon tuleneb ettevõtluse mõiste laiast käsitusest, mille kohaselt on ettevõtluspädevus terviklik kogum teadmisi, oskusi ja hoiakuid, mis on vajalikud väärtuse loomiseks ideede elluviimisel, õppija ettevõtlikkuse arenguks ning jätkusuutlikuks toimetulekuks tööl ja igapäevaelus. Kokku on ettevõtluspädevuse mudelis neli pädevusvaldkonda (joonis 1), mis moodustavad ettevõtluse definitsiooni alusel kaks alajaotist: ettevõtlusõpe kui eriala (äriideede elluviimine) ja ettevõtlusõpe kui ettevõtlikkust arendav meetod (ettevõtlikkust toetavate pädevuste, sh enesejuhtimise, väärtust loova mõtlemise ja lahenduste leidmise ning sotsiaalsete olukordade lahendamise 
arendamine õppes). Äriideede elluviimise osa (joonisel varjutatud) peegeldab ettevõtlusõpet selle kitsamas käsituses - ettevõtlusõpe on uue ettevõtte loomiseks vajalike pädevuste arendamine. Samas on äriideede elluviimiseks vaja olla ettevõtlik. Ettevõtlusprotsessis on hädavajalikud nii erialased pädevused kui ka ettevõtlikkus ja selle aluseks olevad pädevused (joonisel varjutamata).

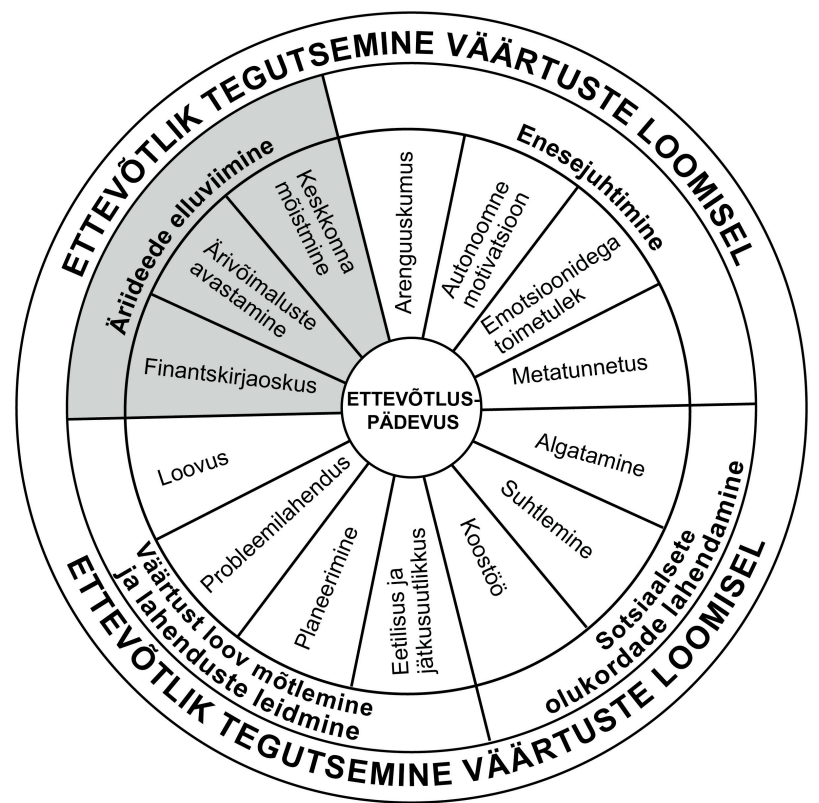

Joonis 1. Ettevõtluspädevuse mudeli struktuur

Ettevõtlusõppe (selle laiemas käsituses) kui ettevõtlikkust toetava meetodi rakendamiseks tuleb arendada enesejuhtimise, väärtust loova mõtlemise ja lahenduste leidmise ning sotsiaalsete olukordade lahendamise valdkonna alapädevusi. Viimati nimetatud valdkonnad moodustavad selle osa ettevõtluspädevusest, mida on vaja loovate ning ettevõtlike inimeste arenguks ühiskonnas. Üldine eeldus on, et ettevõtluspädevust saab arendada ja rakendada kõigil elualadel ning see toetab indiviidi isiklikku arengut, palgatöötajana või iseendale tööandjana sisenemist tööturule, samuti aktiivset ja jätkusuutlikkust väärtustavat osalemist ühiskonnaelus.

Mudeli pädevusvaldkondade ning kitsamalt alapädevuste valikul on arvestatud pädevuste olulisust ja tõenduspõhisust, tuginedes varasematele uurimistulemustele. Samuti ei pruugi alapädevused indiviidi terviklikku toimimist arvesse võttes kuuluda vaid ühte pädevusvaldkonda, vaid kõik pädevusvaldkonnad on omavahel tihedalt põimunud. Näiteks on äriideede elluviimine seotud kõigi ettevõtlikkust toetavate alapädevustega, sh loovuse, probleemilahendus- 
oskuse, planeerimise, emotsioonide juhtimisega. Emotsioonide juhtimine, mis paikneb enesejuhtimise pädevusvaldkonnas, väljendub omakorda suhtlemisel, kaasa arvatud meeskonnatöös, ja seda läheb vaja sotsiaalsete olukordadega toimetulekul. Enesejuhtimise eristamine eraldiseisva pädevusvaldkonnana aitab aga rõhutada edukaks toimetulekuks vajaminevaid pädevusi ja loob eeldused nende teadlikuks arendamiseks ettevõtlusõppes.

Olenevalt õppetsükli pikkusest ning protsessis osalejate motivatsioonist, kavatsustest ja eesmärkidest võib ettevõtlusõppes äriideede elluviimise tulemus olla toote või teenuse arendamine, potentsiaalse ettevõtte ärimudeli kavandamine, äriplaani kirjutamine, uue ettevõtte asutamine vms. Ideid võidakse õppeprotsessis ellu viia ka erialaainetes (nt elektroonika-, logistikaainetes), kus arendatakse mõnd toodet või teenust, või sotsiaalsete probleemide lahendamisel. Seega saab laiendada mudeli kasutusala nii, et see hõlmab peale ettevõtlusõppe ka teisi õppekavade üld- ja erialaaineid, võimaldades arendada eelkõige selliseid pädevusi, mis toetavad ettevõtlikkust ning mis kuuluvad mudeli kolme valdkonda (enesejuhtimine, väärtust loov mõtlemine ning lahenduste leidmine ja sotsiaalsete olukordade lahendamine). Seejuures võib ettevõtlusprotsess eri keskkondades ideede arendamisel varieeruda, sõltudes täpsest sisust, sihtrühma iseärasustest ja väliskeskkonna teguritest.

Kokkuvõttes, kõik kirjeldatud alapädevused on olulised, arendatavad ja omavahel tihedalt põimunud ning moodustavad ühtse terviku - ettevõtluspädevuse. See tähendab, et iga õppija on võimeline arendama igas valdkonnas mõnd pädevust, kuid eri tasemel ja viisil, mis sõltub vanusest, haridusest ja/ või varasemast kogemusest. Pädevuste arendamise eeldus on teadlikkus õppija tugevatest ja nõrkadest külgedest ehk pädevuste tasemest ning õppija uskumine oma intellektuaalsete võimete arendamise võimalikkusse (Dweck, 2016). Õppija pädevuste arendamist tuleb toetada teadlikult ehk seada talle óppetöös arengueesmärke ja hinnata nende saavutamist. Ettevõtluspädevuse arendamine erineb haridustasemeti, nt üldhariduses on tähtis arendada ettevõtlikkusega seotud alapädevusi ja kõrghariduses äriideede elluviimisega seotud alapädevusi. Ettevõtlikkust toetavaid alapädevusi (enesejuhtimine, väärtust loov mõtlemine ja lahenduste leidmine) tuleks hakata arendama hiljemalt algkoolis. Võimalusi arendada ettevõtlusalaseid teadmisi ja oskusi äriideede elluviimiseks tekib põhikoolis ja gümnaasiumis ning need muutuvad oluliseks kutse- ja kõrghariduses.

Toetudes ettevõtluse ja ettevõtluspädevuse definitsioonile ning viidates programmi „Edu ja tegu“ eesmärgile luua alus ettevõtlikkuse ja ettevõtlusõppe süsteemseks arendamiseks, täidab artiklis esitatud mudel kahte ülesannet: 1) toetab loovate ja ettevõtlike inimeste arengut ühiskonnas ning 2) loob aluse ettevõtlusõppe programmide/kursuste arendamiseks. Esimene ülesanne on 
püstitatud selleks, et pakkuda lahendusi ettevõtlusõppe lõimimiseks õppekavadesse (üld- ja erialaainetesse), sidudes aineõppe elulise kontekstiga ja toetades seeläbi õppijate ettevõtlikkuse arengut. Teine ülesanne on aluseks ettevõtlusõppe õpiväljundite, sisu ja õppemeetodite arendamisele. Lähtudes eelkirjeldatust ja varem loodud tervikliku pädevusmudeli põhimõtetest (nt Le Deist \& Winterton, 2005), võib väljapakutud mudelit pidada teoreetiliselt terviklikuks, kuna see sisaldab pädevusi, mis võimaldavad luua mitmesugustes keskkondades ideede elluviimiseks vajalikke väärtusi.

\section{Ettevõtluspädevuse valdkonnad ja alapädevused}

Et kiirelt muutuvas ettevõtluskeskkonnas ootamatute olukordadega ja üha suuremate ühiskondlike katsumustega toime tulla, on vaja arendada mitmesuguseid teadmisi ja oskusi. Erinevad pädevused (nt enesejuhtimine, mõtlemisoskused, sotsiaalsed oskused ja äriideede elluviimiseks vajalikud valdkonnaspetsiifilised oskused) soodustavad paremat toimetulekut, sh paindlikku tegutsemist kiirelt muutuvates oludes.

\section{Enesejuhtimine}

Enesejuhtimine sisaldab uskumist oma võimete arendatavusse, meisterlikkusele suunatust, autonoomset motivatsiooni ja emotsioonidega toimetuleku oskusi. Lisaks on ettevõtluskeskkonnas tegutsemisel oluline metatunnetus ehk oskus iseenda mõtteid, tundeid ja käitumist märgata ning suunata ja vajaduse korral neid paindlikult reguleerida (Efklides, 2011, 2014; Flavell, 1979) See on tegutsemise efektiivsuse seisukohalt oluline tegur, olles tugevalt seotud nii mõtlemisoskuste kui ka oma pingutuse ja motivatsiooni suunamisega.

Emotsioonidega toimetulek on tähtis, sest ettevõtlusega seostuvad nii positiivsed emotsioonid (Schindehutte, Morris, \& Allen, 2006) kui ka töökoormusest, vastutusest ja määramatusest tulenevad negatiivsed emotsioonid, mis võivad põhjustada ärevust, stressi ja läbipõlemist (Patzelt \& Shepherd, 2011). Seega muutub oluliseks võime oma emotsioone märgata ja ära tunda ning olla teadlik emotsioonide reguleerimise viisidest ja osata neid olukorrale vastavalt kasutada (nt Garnefski \& Kraaij, 2006).

Autonoomset motivatsiooni võib pidada ettevõtlikkuse ja enesejuhitud tegutsemise aluseks. See hõlmab tegevuste algatamist, ideede pakkumist, otsustamist ja vastutuse võtmist ilma välise surveta. Sellise motivatsiooni korral on tegevus tegutseja enda perspektiivist mõtestatud ja väärtustatud ja/või tema jaoks huvitav (Deci \& Ryan, 2000) ning see seostub ootuspäraselt nii suurema püsivusega tagasilöökide korral kui ka paremate pikaajaliste tulemustega. 
Arenguuskumus tähendab uskumust või mõtteviisi, et inimeste võimeid ja omadusi saab arendada eri tegutsemisstrateegiate proovimise, pingutamise ja enda proovilepaneku kaudu ning et tagasilöögid ei ole märk võimetusest, vaid arengu loomulik osa (Dweck \& Leggett, 1988). Arenguuskumusega kaasnevad üldjuhul suurem püsivus ning pikas perspektiivis paremad tulemused pingutamist eeldavates olukordades.

Kõik eespool nimetatud alapädevused, mis on seotud enesejuhtimise valdkonnaga, on olulised ettevõtluskeskkonnast tingitud raskustega toimetulekul ja muutuvad eriti vajalikuks uudsetes olukordades, kus puudub probleemidele üks ja õige lahendus.

\section{Väärtust loov mõtlemine ja lahenduste leidmine}

Väärtust loova mõtlemise ja lahenduste leidmise pädevusvaldkond on seotud mõtlemisoskustega. Mõtlemine on oma kogemuse ja sellele vastava tegevuse seesmine organiseerimine (Toomela, 2003), seevastu tegutsemise edukus on seotud eri viisidega, kuidas teadmisi ja kogemusi struktureeritakse. Mõtlemisoskused võimaldavad kasutada olemasolevaid teadmisi süsteemselt ja teadlikult ning luua seeläbi uut väärtust. Samuti on süsteemne mõtlemine aluseks eetilisele ja jätkusuutlikule tegutsemisele, ettevõtlustegevuse võimalike tagajärgede mõistmisele, tulevikustsenaariumide mudeldamisele ja pikas perspektiivis kestlike otsuste langetamisele. Süsteemne mõtlemine võimaldab analüüsida kriitiliselt enda ja teiste tegevuse efektiivsust, otsustada autonoomselt, analüüsida ettevõtlusprotsessi tähendust seoses ümbritsevaga nii lühi- kui ka pikaajalises perspektiivis, järgides teadlikult ja järjekindlalt jätkusuutlikke ning eetikapõhimõtteid.

Eetilisuse ja jätkusuutlikkuse alapädevus on lisatud mõtlemisoskuste valdkonda, sest selle eeldus on kriitiline ja teadmistepõhine arutlemisoskus. See alapädevus loob süsteemse mõtlemise abil aluse sellisele otsustamisele, planeerimisele ja tegutsemisele, mis võtavad majanduslikku jätkusuutlikkust silmas pidades arvesse ka ettevõtliku tegevuse mõju looduskeskkonna säilenõtkusele, kogukonna lokaalsele ja globaalsele heaolule ning püüab neid võimaluse korral paremaks, mitte halvemaks muuta. Loovus on protsess, mille tulemusena tekivad uudsed (ja kasulikud) seosed ja lahendused. Ettevõtluses on loovus põhiline edukuse eeldus ja see toetab keeruliste probleemide lahendamist (Karimi et al., 2014). Ettevõtluses väljenduvat loovust nähakse tihti indiviidide koostöö ja keskkonna koosmõju tulemina (Sawyer, 2012; Sternberg, 2006). Tõelise loovuse ilmnemine eeldab sügavaid teadmisi ning loovuse järjepidevat arendamist (Ericsson, Krampe, \& Tesch-Römer, 1993). 
Probleemilahendusoskus on põimitud loovusega ning väljendub probleemide märkamises, analüüsimises ja uudsete lahenduste väljapakkumises (Kelley \& Littman, 2001; Sawyer, 2012; Scott, Leritz, \& Mumford, 2004; Sternberg, 2006). Probleemilahendust on kirjeldatud oskusena probleemi märgata, määratleda ja esitada, lahendusi pakkuda ning nende hulgast sobiv valida, tegevust planeerida, viia lahendus ellu ning hinnata, kas saavutatu vastab seatud eesmärgile ja kui edukas oldi probleemi lahendajana (nt Kapur, 2015; Kikas, 2015). Mitmes teoreetilises käsitluses juhitakse tähelepanu ka planeerimisoskustele, kuna probleemilahendusprotsessi eri etappides on vaja teha eesmärgipäraseid valikuid ja otsustada, kuidas tulemuste saavutamiseks edasi liikuda.

\section{Sotsiaalsete olukordade lahendamine}

Sotsiaalset pädevust võib üldistatult mõista kui indiviidi toimetulekut sotsiaalsetes olukordades (Beauchamp \& Anderson, 2010) ning selle all mõeldakse enamasti just suhtlemis- ja koostööoskuste rakendamist inimesi kaasavates olukordades (Kjellberg \& Haglund, 2016). Sotsiaalne pädevus on oluline ettevõtluses, sest ärisidemed ja -võrgustikud laienevad organisatsioonidele, kultuuridele ja ühiskondadele ning see eeldab inimeste teadlikkust ja suhtlust meeskondades ja muudes inimvõrgustikes (nt Cheruvelil et al., 2014). Mudelis on sotsiaalne pädevus jagatud algatamiseks, suhtlemiseks ja koostööks. Sotsiaalsed pädevused on omavahel põimunud ja üks pädevus võib olla teise sisend (nt koostööoskus eeldab suhtlemisoskust) ning neid rakendatakse sageli koos.

Algatamine on kombinatsioon enesejuhtimisest, planeerimisest ja valdkonna teadmistest ning sündmusi ennetav, pikaajalisele perspektiivile ja püsivusele keskenduv töine käitumine (Frese \& Fay, 2001). Algatusvõime tähendab muu hulgas võimaluste märkamist ja kasutamist ning vastuvõtlikkust uutele ideedele (DeShon \& Gillespie, 2005), inspireerivat, kaasavat, võimestavat ja loovat tegutsemist, motiveerimisoskust ning kalkuleeritud riskide võtmist (Bartram, 2005).

Suhtlemine eeldab eneseväljendust ja suhtluskaaslaste mõistmist (Dube \& Marnewick, 2015) ning väljendub emotsioonide reguleerimise võimes ja teistega läbisaamises. See ühendab suhtlusoskused eneseteadlikkuse, enesejuhtimise, sotsiaalse teadlikkuse ja vastutustundliku, sh eetikaküsimuste üle otsustamisega (nt Zhou \& Ee, 2012). Suhtlemine peegeldab indiviidi võimekust töödelda sotsiaalset informatsiooni, olla tolerantne, empaatiline ja eetiline, märgata teiste reaktsioone ning reageerida neile asjakohaselt (Bartram, 2005). Ettevõtluse kontekstis eristatakse ka häid ideede esitlemise ja läbirääkimis- 
oskusi ning suutlikkust müüa oma ideid huvirühma ootusi arvestades (Bacigalupo et al., 2016).

Koostöö on edukas ühistöö, mis eeldab ühist pingutust meeskondlike eesmärkide saavutamiseks (Anderson-Butcher et al., 2014; Salas, Cooke, \& Rosen, 2008), juhul kui meeskonnaliikmetel on vajalikud pädevused ja soov meeskonnana töötada (Baker, Day, \& Salas, 2006). Tulemuslikuks meeskonnatööks on vaja harmoonilisi suhteid, jagatud vastutust, töörõõmu ja pühendumist, alles seejärel saavad sünergias tekkida väljapaistvad tulemused (Baker et al., 2006; Salas et al., 2008). Koostööoskuste korral on vaja mõista võrgustiku tähtsust, sh tähtsustada osaliste kaasamist väärtuse loomisel (Bacigalupo et al., 2016).

\section{Äriideede elluviimine}

Äriideede elluviimine väljendub ettevõtlusõppe puhul eelkõige ettevõtluse kitsamas tähenduses. Seda saab rakendada ettevõtlusega alustamisel, tegutsevas ettevõttes uute toodete arendamisel ja turule toomisel ning muude uuenduste tegemisel, samuti mitmesugustes sotsiaalsetes olukordades. Äriideede elluviimise tuumaks on ettevõtlusprotsess, kus indiviid aktiivselt osaledes panustab väärtuse loomisse ja kus tema ettevõtlikkus on otsustava tähtsusega ärivõimaluste avastamisel (Baggen et al., 2018). Vaatlusalune valdkond sisaldab alapädevustest ärivõimalusi, keskkonna mõistmist ja finantskirjaoskust, mis kõik on vajalikud edukaks tegutsemiseks ettevõtluskeskkonnas.

Ärivõimaluste alapädevus hõlmab info otsimist ja turuteadlikkust, mis võimaldavad võimalusi märgata, hinnata ja ära kasutada. Informatsiooni otsimise ja seostamise oskus ning tähelepanelikkus valdkonnas toimuva suhtes on vajalikud nii ettevõtlustegevuses kui ka laiemalt ettevõtlikus tegutsemises (nt ettevõttes töötajana või igapäevaelus). Ärivõimaluste avastamiseks turul on vaja turualaseid teadmisi-oskusi. Teadlikkus turust on oskus tajuda võimalike klientide vajadusi ja seostada neid enda ettevõtlustegevusega, samuti on see seotud oskusega tajuda, mida teevad turul konkurendid (van der Laan, Driessen, \& Zwart, 2010). Niisama tähtis on mõista laiemat keskkonda, mis mõjutab ärivõimaluste avastamise ja nende rakendamise protsessi.

Keskkonna mõistmine tähendab võimet orienteeruda ettevõtluskeskkonnas (nt jälgida poliitilist, majanduslikku, sotsiaalset, tehnoloogilist, ökoloogilist keskkonda) ja eri tasanditel (nt kohalik, riiklik, globaalne tasand) ning seega analüüsida keskkonna mõju väärtust loovatele, sh ettevõtlustegevustele (Rasmussen \& Nybye, 2013). Keskkonna mõistmisel on tähtis arvesse võtta kultuuride iseärasusi, sh kliente, partnereid. Keskkonnateadlikkus tagab ettevõtluses pikaajalise edu, kui eesmärgiks võetakse ettevõtte kestlik majandamine ja arvestatakse keskkonnamõjuga, mille tulemusena luuakse jätkusuutlikke 
tooteid/teenuseid, tootmistehnoloogiaid ja ettevõtte juhtimise protsesse (Lans, Blok, \& Wesselink, 2014).

Finantskirjaoskus on rahaasjade ja nendega seotud riskide teadmine ning mõistmine, motivatsioon ja kindlus neid teadmisi igasugustes olukordades hästi ära kasutada, millega parandatakse isiklikku ja ühiskondlikku rahalist heaolu ning võimaldatakse majanduselus osalemist (OECD, 2016). Finantskirjaoskus on ressursside mobiliseerimiseks vajalik pädevus, samuti oskus pika aja jooksul juhtida väärtust loova tegevuse finantseerimist nii ettevõtluses kui ka indiviidina (ibid.).

\section{Metoodika}

Artikli empiirilises osas vastatakse teisele uurimisküsimusele ehk põhjendatakse empiiriliselt ettevõtluspädevuse mudelis sisalduvate alapädevuste valikut ja alapädevustevahelisi seoseid, et hinnata mudeli ja alapädevuste usaldusväärsust. Samuti käsitletakse pädevuste mõõtmiseks valitud hindamisvahendi algupära. Hindamisvahend koosneb varasematele uuringutele tuginevatest küsimustikest, millest igaüks võimaldab hinnata üht alapädevust. Küsimustikud on tõlgitud inglise keelest, nende kohandamisel on lähtutud ettevõtluspädevuse mudeli alapädevuste kirjeldusest.

\section{Valim}

Uurimuse andmed koguti 2017. aasta kevadel ja sügisel Eesti kõrgkoolidest internetiküsimustikuga, mille eesmärk oli hinnata ettevõtluspädevuse mudeli alapädevuste vahelisi seoseid ja enesehindamisvahendi rakendatavust. Valimi suurus oli $N=1479$ inimest. Rakenduskõrghariduse üliõpilasi oli 131 (9\%), bakalaureusetaseme üliõpilasi 689 (47\%), magistritaseme üliõpilasi 625 (42\%) ning muu taseme (üli)õpilasi 34 (2\%). Naisi oli vastanute hulgas 912 (62\%) ning mehi $567(38 \%)$. Vastajate keskmine vanus oli $26,39(\mathrm{~min}=16, \max =66$, $S D=8,06)$.

\section{Hindamisvahendid}

Uuringus kasutati õppija ettevõtluspädevuse hindamise küsimustikku - ülesannete ja küsimuste kogumit, mis on esitatud alapädevuste kaupa. Enesehindamise küsimustikud tuginevad erinevatele teoreetilistele käsitlustele ja varasematele uurimustele ning neid katsetati Eesti kõrgkoolides.

Küsimustikud koosnesid enesekohastest väidetest, millele sai vastata viiepallisel Likerti skaalal, milles 5 tähendas väitega täielikult nõustumist ja 1 mitte- 
nõustumist. Lisaks said vastajad valida „Ei oska öelda“. Tulemuste analüüsis kasutati keskmisi skoore. Valiku „Ei oska öelda“ vastuseid analüüsi ei lisatud. Järgnevalt on iseloomustatud iga ettevõtluspädevuse valdkonna alapädevuste kaupa nende hindamiseks valitud väiteid ja esitatud allikaid.

\section{Enesejuhtimise küsimustikud}

Enesejuhtimist hinnati arenguuskumuste ja emotsioonidega toimetuleku küsimustikuga. Arenguuskumuste küsimustik tugines Karwowski (2014) tööle ning sisaldas viit väidet loovusega seotud jäävususkumuste kohta (nt „Mõned inimesed lihtsalt on loovad ja teised mitte. Ôppimine seda ei muuda“). Emotsioonidega toimetuleku küsimustik põhines Cognitive Emotion Regulation Questionnaire'il (CERQ, Garnefski, \& Kraaij, 2006) ning see kohandati ettevõtlikkuse konteksti. Vastaja pidi hindama, kuidas ta kirjeldatud olukorras mõtleks. Mõõtmiseks kasutati kahte koondskoori (kummaski neli väidet): 1) kohanemist toetavad väited, mis kirjeldavad emotsiooni reguleerimise strateegiaid (nt „Mõtlen, mida ma sellest olukorrast õppisin“) ja 2) kohanemist mittetoetavad väited, mis kirjeldavad emotsioonide reguleerimise strateegiaid (nt „Mõtlen selle ebaõnnestumise peale korduvalt ka edaspidi“).

\section{Väärtust loova mõtlemise ja lahenduste leidmise küsimustikud}

Väärtust loovat mõtlemist ja lahenduste leidmist hinnati loovuse, probleemilahenduse, planeerimise ja väärtuspõhisuse küsimustikuga. Loovuse küsimustik tugineb Karwowski (2014) töödele ning sisaldab kuut väidet, millega mõõdetakse loovusega seotud enesetõhusust (nt „Olen kindel, et saan hakkama probleemidega, mis nõuavad loovaid lahendusi“). Probleemilahenduse ja planeerimise küsimustiku koostamisel lähtuti Dawsoni ja Guare (2011) küsimustikust, millel oli kaks alaskaalat (paindlikkus ja ajaplaneerimine), kummaski kolm väidet. Paindlikkust hinnati nt väitega „Ma suudan teha enda plaanides lihtsasti muudatusi, kui olukord seda nõuab“ ning ajaplaneerimist nt väitega „Enda päeva planeerides sean ülesanded tähtsuse järjekorda“. Väärtuspõhisuse küsimustik oli koostatud Buili, Aznari, Galiana ja Rocafort-Marco (2016) töö alusel ning see sisaldas kaht alaskaalat: sotsiaalset ja keskkonnale pühendumist. Siinses uuringus moodustus nendest üks faktor, mis koosnes viiest väitest (nt „Ettevõtted peaksid oma tegevusega toetama kogukonda/ühiskonda“). 


\section{Sotsiaalsete protsesside juhtimise küsimustikud}

Sotsiaalsete protsesside juhtimist hinnati algatamise, suhtlemise ja koostöö küsimustikuga. Algatamise küsimustik toetus Frese (2009) tööle ning koosnes seitsmest väitest (nt „Kui on võimalus olla kuskile aktiivselt kaasatud, siis kasutan seda viivitamatult"). Suhtlemise küsimustiku aluseks võeti Zhou ja Ee (2012) sotsiaalse emotsionaalse kompetentsuse küsimustik. Küsimustikul oli kaks alaskaalat (kumbki nelja väitega): 1) sotsiaalne teadlikkus (nt „Mul on lihtne mõista, miks inimesed tunnevad ennast ühel või teisel viisil“") ja 2) suhete juhtimine (nt „Ma vabandan alati, kui solvan tahtmatult kellegi tundeid“). Koostöö küsimustiku koostamisel lähtuti Loweri, Newmani ja Anderson-Butcheri (2015) meeskonnatöö küsimustikust, millel oli kuus väidet (nt „Ma väärtustan teiste grupikaaslaste panust").

\section{Äriideede elluviimise küsimustikud}

Äriideede elluviimist hinnati ärivõimaluste avastamise ja finantskirjaoskuste küsimustikuga. Ärivõimaluste avastamise küsimustik tugines Tangi, Kacmari ja Busenitzi (2012) ning Kyndti ja Baerti (2015) tööle ning koosnes kuuest väitest (nt „Püüan uut informatsiooni otsides alati avastada uusi ärivõimalusi“). Finantskirjaoskuste küsimustiku aluseks oli Kyndti ja Baerti (2015) finantsteadlikkuse küsimustik, millel oli kuus väidet (nt „Ma tean, kuidas oma kulutusi kontrolli all hoida").

\section{Analüïsimeetodid}

Andmeid analüüsiti programmiga IBM SPSS Statistics 24. Küsimustike faktorstuktuuri kontrollimiseks kasutati eksploratiivset faktoranalüüsi kaldpööramisega (direct oblimin, $\delta=0$ ). Moodustunud faktorite alusel arvutati iga alaskaala seesmise reliaabluse näitaja (Cronbachi $\alpha$ ) ning keskmine tulemus. Seoseid analüüsiti Pearsoni korrelatsioonanalüüsiga, statistiliselt olulised tulemused esitatakse olulisusnivool $\alpha=0,01$. 


\section{Tulemused}

\section{Faktoranalüïsi tulemused}

Tabelites 1-4 on esitatud eksploratiivse faktoranalüüsi tulemusena leitud faktorite laadungid. Tulemused näitavad, et väärtust looval mõtlemisel ja lahenduste leidmisel eristub neli faktorit: loovus, paindlikkus, ajaplaneerimine ja väärtuspõhisus (tabel 1).

Tabel 1. Väärtust loova mõtlemise ja lahenduste leidmise faktorite laadungid ning kommunaliteedid

\begin{tabular}{|c|c|c|c|c|c|}
\hline \multirow[t]{2}{*}{ Alaskaala } & \multicolumn{4}{|c|}{ Faktorlaadungid } & \multirow[t]{2}{*}{ Kommunaliteedid } \\
\hline & I & II & III & IV & \\
\hline Loovus 1 & 0,59 & & & & 0,46 \\
\hline Loovus 2 & 0,82 & & & & 0,66 \\
\hline Loovus 3 & 0,79 & & & & 0,57 \\
\hline Loovus 4 & 0,75 & & & & 0,60 \\
\hline Loovus 5 & 0,86 & & & & 0,74 \\
\hline Loovus 6 & 0,78 & & & & 0,60 \\
\hline Paindlikkus 1 & & 0,71 & & & 0,53 \\
\hline Paindlikkus 2 & & 0,88 & & & 0,74 \\
\hline Paindlikkus 3 & & 0,82 & & & 0,72 \\
\hline Ajaplaneerimine 1 & & & 0,77 & & 0,58 \\
\hline Ajaplaneerimine 2 & & & 0,72 & & 0,57 \\
\hline Ajaplaneerimine 3 & & & 0,69 & & 0,47 \\
\hline Väärtuspõhisus 1 & & & & 0,64 & 0,40 \\
\hline Väärtuspõhisus 2 & & & & 0,55 & 0,30 \\
\hline Väärtuspõhisus 3 & & & & 0,65 & 0,44 \\
\hline Väärtuspõhisus 4 & & & & 0,75 & 0,61 \\
\hline Väärtuspõhisus 5 & & & & 0,72 & 0,54 \\
\hline
\end{tabular}

Märkus. Faktorlaadungid $<0,40$ on tabelist välja jäetud. 
Sotsiaalsete olukordade lahendamisel eristub neli faktorit: algatamine, sotsiaalne teadlikkus, suhete juhtimine ja koostöö (tabel 2).

Tabel 2. Sotsiaalsete olukordade lahendamise faktorite laadungid ja kommunaliteedid

\begin{tabular}{|c|c|c|c|c|c|}
\hline \multirow[t]{2}{*}{ Küsimustik } & \multicolumn{4}{|c|}{ Faktorlaadungid } & \multirow[t]{2}{*}{ Kommunaliteedid } \\
\hline & I & II & III & IV & \\
\hline Algatamine 1 & 0,57 & & & & 0,35 \\
\hline Algatamine 2 & 0,76 & & & & 0,59 \\
\hline Algatamine 3 & 0,81 & & & & 0,65 \\
\hline Algatamine 4 & 0,72 & & & & 0,55 \\
\hline Algatamine 5 & 0,67 & & & & 0,50 \\
\hline Algatamine 6 & 0,58 & & & & 0,44 \\
\hline Algatamine 7 & 0,65 & & & & 0,47 \\
\hline Sotsiaalne teadlikkus 1 & & 0,76 & & & 0,57 \\
\hline Sotsiaalne teadlikkus 2 & & 0,85 & & & 0,73 \\
\hline Sotsiaalne teadlikkus 3 & & 0,81 & & & 0,66 \\
\hline Sotsiaalne teadlikkus 4 & & 0,71 & & & 0,55 \\
\hline Suhete juhtimine 1 & & & 0,61 & & 0,46 \\
\hline Suhete juhtimine 2 & & & 0,84 & & 0,66 \\
\hline Suhete juhtimine 3 & & & 0,76 & & 0,60 \\
\hline Suhete juhtimine 4 & & & 0,64 & & 0,51 \\
\hline Koostöö 1 & & & & 0,70 & 0,46 \\
\hline Koostöö 2 & & & & 0,53 & 0,36 \\
\hline Koostöö 3 & & & & 0,57 & 0,52 \\
\hline Koostöö 4 & & & & 0,80 & 0,62 \\
\hline Koostöö 5 & & & & 0,73 & 0,53 \\
\hline Koostöö 6 & & & & 0,56 & 0,38 \\
\hline
\end{tabular}

Märkus. Faktorlaadungid $<0,40$ on tabelist välja jäetud. 
Enesejuhtimisel eristub kolm faktorit: jäävususkumused, emotsioonidega toimetulekut mittetoetavad strateegiad ja emotsioonidega toimetulekut toetavad strateegiad (tabel 3).

Tabel 3. Enesejuhtimise faktorite laadungid ja kommunaliteedid

\begin{tabular}{lccc}
\hline Küsimustik & \multicolumn{2}{c}{ Faktorlaadungid } & Kommunaliteedid \\
\hline & I & II & III \\
Jäävususkumused 1 & 0,79 & & 0,63 \\
\hline Jäävususkumused 2 & 0,82 & 0,70 \\
\hline Jäävususkumused 3 & 0,67 & & 0,44 \\
\hline Jäävususkumused 4 & 0,80 & & 0,66 \\
\hline Jäävususkumused 5 & 0,66 & & 0,44 \\
\hline ETd mittetoetavad strateegiad 1 & & 0,65 & 0,41 \\
\hline ETd mittetoetavad strateegiad 2 & & 0,75 & 0,54 \\
\hline ETd mittetoetavad strateegiad 3 & & 0,65 & 0,50 \\
\hline ETd mittetoetavad strateegiad 4 & & 0,61 & 0,38 \\
\hline ETd toetavad strateegiad 1 & & 0,51 & 0,28 \\
\hline ETd toetavad strateegiad 2 & & 0,69 & 0,49 \\
\hline ETd toetavad strateegiad 3 & & 0,68 & 0,49 \\
\hline ETd toetavad strateegiad 4 & & 0,59 & 0,35 \\
\hline
\end{tabular}

Märkused. ET - emotsioonidega toimetulek. Faktorlaadungid $<0,40$ on tabelist välja jäetud.

Äriideede elluviimisel eristub kaks faktorit: ärivõimaluste avastamine ja finantskirjaoskus (tabel 4).

Tabel 4. Äriideede elluviimise faktorite laadungid ja kommunaliteedid

\begin{tabular}{|c|c|c|c|}
\hline \multirow[t]{2}{*}{ Küsimustikud } & \multicolumn{2}{|c|}{ Faktorlaadungid } & \multirow[t]{2}{*}{ Kommunaliteedid } \\
\hline & I & II & \\
\hline Ärivõimaluste avastamine 1 & 0,61 & & 0,41 \\
\hline Ärivõimaluste avastamine 2 & 0,64 & & 0,45 \\
\hline Ärivõimaluste avastamine 3 & 0,70 & & 0,49 \\
\hline Ärivõimaluste avastamine 4 & 0,68 & & 0,46 \\
\hline Ärivõimaluste avastamine 5 & 0,78 & & 0,60 \\
\hline Ärivõimaluste avastamine 6 & 0,77 & & 0,56 \\
\hline
\end{tabular}




\begin{tabular}{|c|c|c|}
\hline \multirow[t]{2}{*}{ Küsimustikud } & Faktorlaadungid & \multirow[t]{2}{*}{ Kommunaliteedid } \\
\hline & II & \\
\hline Finantskirjaoskus 1 & 0,76 & 0,56 \\
\hline Finantskirjaoskus 2 & 0,73 & 0,56 \\
\hline Finantskirjaoskus 3 & 0,81 & 0,64 \\
\hline Finantskirjaoskus 4 & 0,78 & 0,59 \\
\hline Finantskirjaoskus 5 & 0,73 & 0,52 \\
\hline Finantskirjaoskus 6 & 0,67 & 0,49 \\
\hline
\end{tabular}

Märkus. Faktorlaadungid $<0,40$ on tabelist välja jäetud.

\section{Kirjeldavad statistikud ja alaskaaladevahelised seosed}

Tabelis 5 on esitatud kõigi küsimustikes olevate väidete arvud, minimaalsed ja maksimaalsed skoorid, keskmised, standardhälbed ning seesmise reliaabluse näitajad (Cronbachi $\alpha$ ). Tulemused osutavad, et enamikul faktoritest on head seesmise reliaabluse näitajad, kuid enesejuhtimise all oleva emotsioonidega toimetuleku faktori seesmise reliaabluse näitaja on teistest mõnevõrra väiksem $(\alpha=0,49)$.

Tabelis 6 on esitatud kõigi faktorite vahelised seosed (Pearsoni korrelatsioon). Tulemustest ilmneb, et kõik väärtust loova mõtlemise ja lahenduste leidmise faktorid on omavahel statistiliselt olulisel määral positiivselt seotud $(r=0,12-0,43, p<0,01)$. Samuti on statistiliselt oluline seos sotsiaalsete olukordade lahendamise faktorite vahel $(r=0,24-0,42, p<0,01)$. Enesejuhtimise puhul ilmneb, et statistiliselt oluliselt on omavahel ainsana seotud jäävususkumuse ja emotsioonidega toimetulekut mittetoetavate strateegiate faktorid $(r=0,22, p<0,01)$. Samas emotsioonidega toimetulekut toetavate ja mittetoetavate strateegiate faktorid ei ole omavahel seotud. Äriideede elluviimisel on ärivõimaluste avastamine ja finantskirjaoskus omavahel positiivselt seotud $(r=0,36, p<0,01)$.

Tabelis 6 on esitatud kõigi faktorite vahelised seosed (Pearsoni korrelatsioon). Tulemustest ilmneb, et kõik väärtust loova mõtlemise ja lahenduste leidmise faktorid on omavahel statistiliselt olulisel määral positiivselt seotud $(r=0,12-0,43, p<0,01)$. Samuti on statistiliselt oluline seos sotsiaalsete olukordade lahendamise faktorite vahel $(r=0,24-0,42, p<0,01)$. Enesejuhtimise puhul ilmneb, et statistiliselt oluliselt on omavahel ainsana seotud jäävususkumuse ja emotsioonidega toimetulekut mittetoetavate strateegiate faktorid $(r=0,22, p<0,01)$. Samas emotsioonidega toimetulekut toetavate ja mittetoetavate strateegiate faktorid ei ole omavahel seotud. Äriideede elluviimisel on ärivõimaluste avastamine ja finantskirjaoskus omavahel positiivselt seotud $(r=0,36, p<0,01)$. 


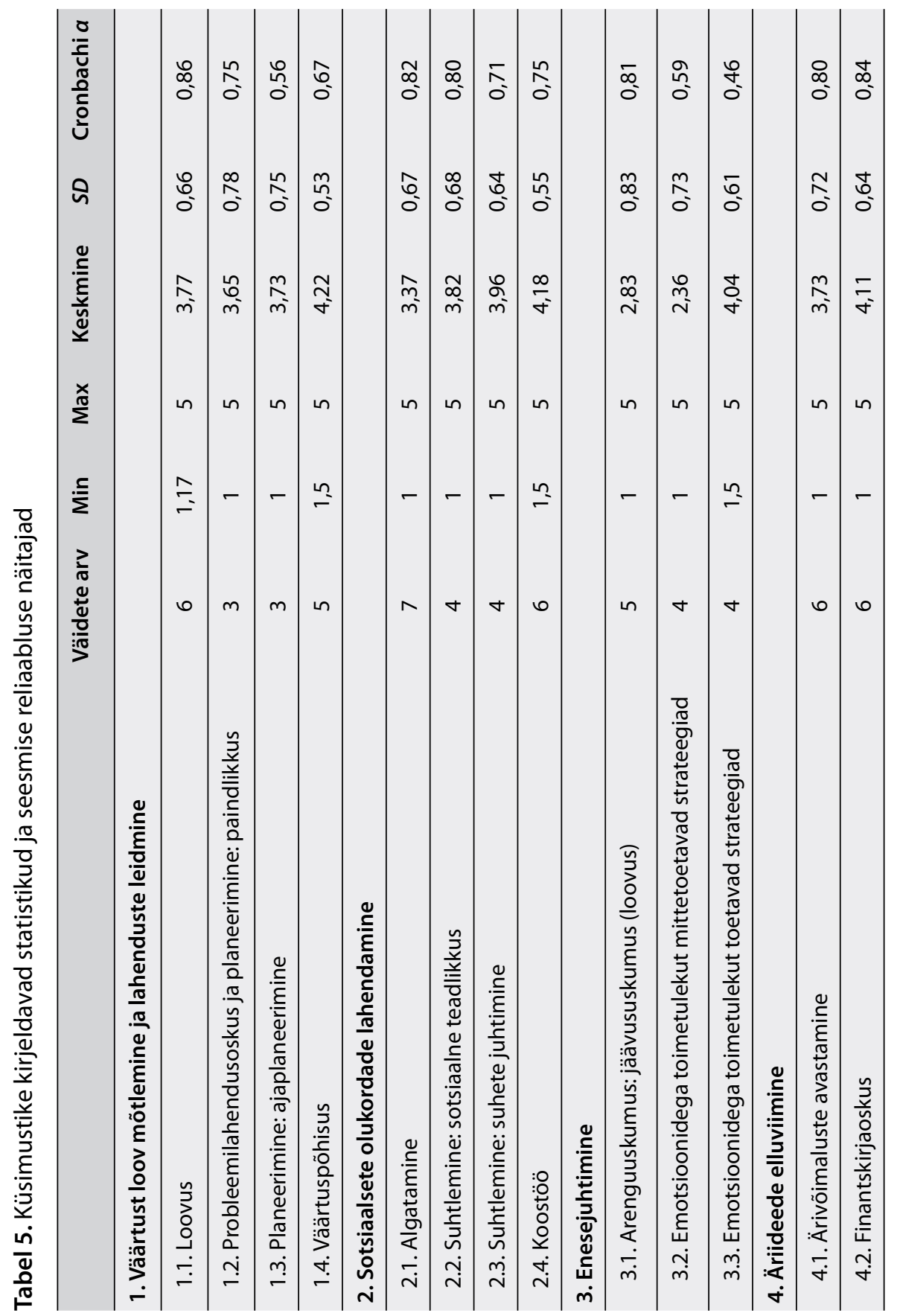




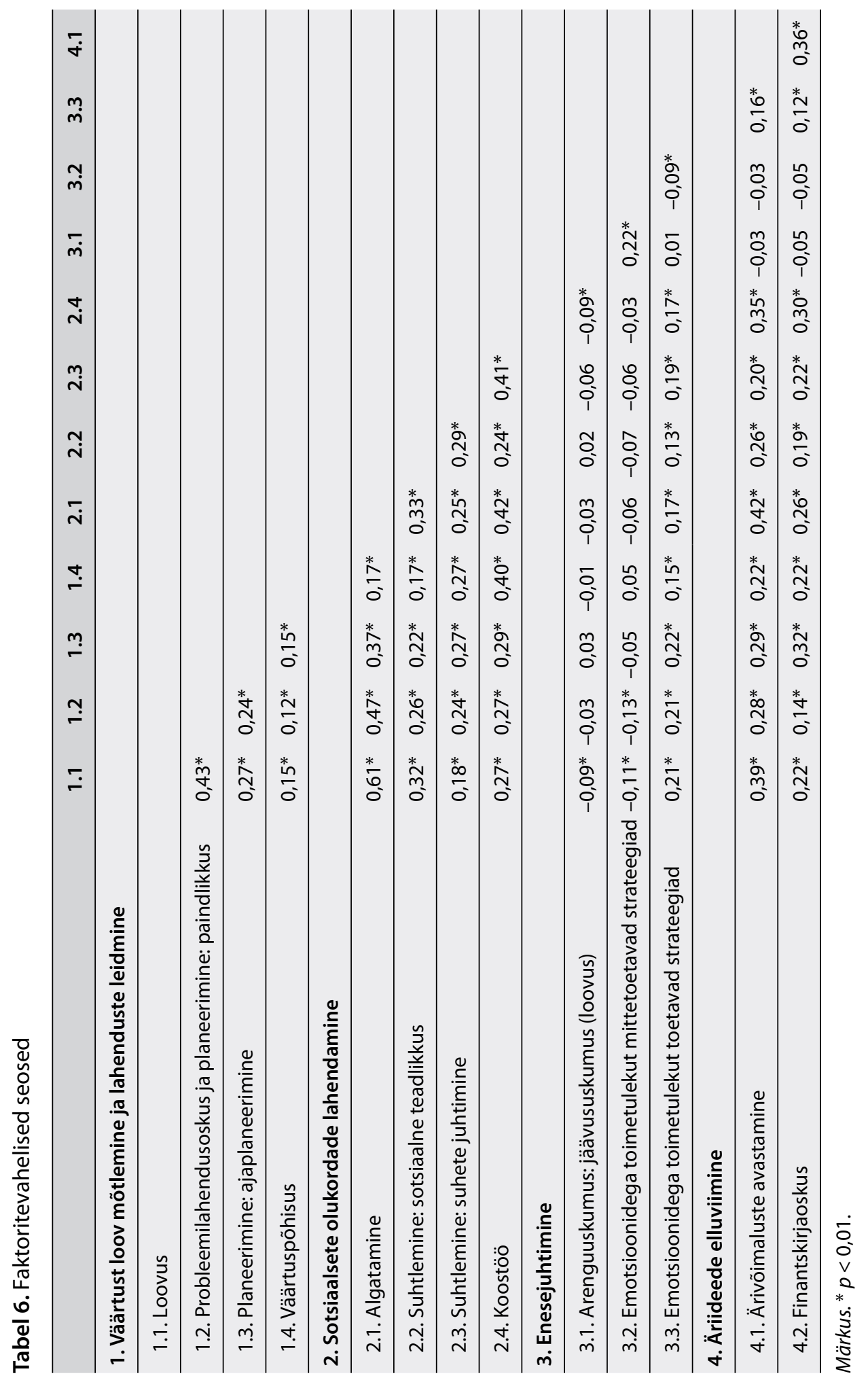


Kokkuvõttes näitavad tulemused, et neljas suuremas pädevusvaldkonnas eristuvad ootuspäraselt erinevad alapädevused. Sealjuures on enamik alapädevustest siiski omavahel positiivselt seotud ehk ühe alapädevuse arendamine võib toetada ka teiste alapädevuste arengut.

\section{Arutelu}

Artikli eesmärk on kirjeldada ja empiiriliselt põhjendada programmi „Edu ja tegu" raames loodud ettevõtluspädevuse mudelit ning selles sisalduvate alapädevuste valikut. Uurimuses kirjeldati mudeli alapädevuste vahelisi seoseid, et põhjendada nende jagunemist mudeli alavaldkondadeks. Uurimuse tulemusena saab väita, et alapädevuste jaotumus on empiiriliste andmete pinnalt mudeldatuna ootuspärane ja vastab teoreetilistele eeldustele, kuid kindlasti ei saa selle põhjal väita, et välja pakutud ettevõtluspädevuse mudel võimaldaks kirjeldada kõiki võimalikke ettevõtlusega tegelemise eeldusi. Mudeli loomisel on alapädevusi valides lähtutud eri teooriatest ning eri valdkondades (nt ettevõtlus, psühholoogia, haridusteadused) tehtud uuringutest, mis võimaldavad alapädevusi seostada toimetulekuga ettevõtluses ning kirjeldada nende arendamise võimalusi ettevõtlusõppes. Järgnevalt tehakse kokkuvõte loodud ettevõtluspädevuse mudelist ja empiirilise uurimuse tulemustest, seostades neid varasema kirjandusega ja lähtudes sõnastatud uurimisküsimustest.

Esimene uurimisküsimus „Mis pädevusi on tarvis, et keskkonnavõimalusi kasutades ideid ellu viia ja nende kaudu väärtusi luua?" sai vastuse töö teoreetilisest osast. Esmalt töötati välja ettevõtluspädevuse mudel, seejärel põhjendati alapädevuste sisu ja mudeli ülesehitust, toetudes nii ettevõtluse kitsale kui ka laiale käsitusele. Mudelis toodud alapädevused, mis on vajalikud õppija ettevõtlikkuse arenguks ning jätkusuutlikuks toimetulekuks töös (sh ettevõtluses) ja igapäevaelus, võib jagada nelja valdkonda: enesejuhtimine, väärtust loov mõtlemine ja lahenduste leidmine, sotsiaalsete olukordade lahendamine ning äriideede elluviimine.

Peale ettevõtluspädevuse mudeli tutvustamise oli uurimuse eesmärk kirjeldada alapädevustevahelisi seoseid kõrgkooliõppijate valimil, otsides vastust teisena sõnastatud uurimisküsimusele „Kuidas empiiriliselt põhjendada ettevõtluspädevuse mudelis sisalduvate alapädevuste valikut?“. Seoste ühtlasemaks kirjeldamiseks valiti töösse need alapädevused, mida mõõdeti järjestusskaalal ning mis sobisid seetõttu paremini andmete töötlemiseks faktoranalüüsi meetodil. Ettevõtluspädevuse alapädevuste seoste analüüs ja faktoranalüüs näitavad, et alapädevustevahelised seosed on loogilised ning kinnitavad osaliselt või täielikult teoreetilise mudeli jagunemist alapädevusteks ja varasemates uurimustes ilmnenud seoseid. Osa alapädevuste juures on näha erisuunalisi 
seoseid teiste alapädevustega, mis osutab vajadusele hindamisvahendit korrigeerida. Mõne alapädevuse suhteliselt mõõdukad seosed teistega viitavad sellele, et alapädevusel on oluline ühisosa teiste pädevustega, kuid nad pakuvad ka ettevõtluspädevuse kujunemisel omaette väärtust. Täpsemaid seoseid on allpool kirjeldatud alavaldkondade kaupa.

Enesejuhtimise pädevusvaldkonnas uuriti arenguuskumusi loovuse valdkonna näitel ning emotsioonidega toimetulekut soodustavaid ja mittesoodustavaid strateegiaid. Faktoranalüüs kinnitas, et kirjeldatud alapädevused eristuvad üksteisest ning omavaheliste seostena paistab silma tendents, et õppijad, kes usuvad, et loovus ei ole muudetav, kalduvad rohkem eelistama ka selliseid strateegiaid, mis ei soodusta emotsioonidega toimetulekut. Ka varem on kirjeldatud, et jäävus- ja arenguuskumused on seotud üleüldise parema toimetuleku ning heaoluga (nt Yeager \& Dweck, 2012). Samuti kasutavad õppijad, kes on enesehinnanguliselt paindlikumad probleemilahendajad, enam adaptiivseid ja vähem mitteadaptiivseid emotsioonide reguleerimise strateegiaid. Selline tulemus on teoreetiliselt ootuspärane, kuna olukordade nägemine teise nurga alt ja nende paindlik mõtestamine ongi emotsioonide adaptiivse reguleerimise olulised mehhanismid. Praeguste uurimistulemuste põhjal võib eeldada, et mudelis sisalduvad enesejuhtimise alapädevused ei hinda ühte ja sama konstrukti, vaid kirjeldavad enesejuhtimise eri tahke. Seost võib põhjendada uskumuste ning emotsioonide juhtimise alapädevuse koondumisega enesejuhtimise valdkonna alla. Enesejuhtimisega on seotud parem teadlikkus enda mõtlemisest ning kasutatavatest strateegiatest, mis omakorda on seotud parema toimetulekuga negatiivseid emotsioone tekitavates olukordades. Eeltoodut arvestades tuleks iga alapädevuse arendamisele teadlikult tähelepanu pöörata, kuid samas on vaja mõista alapädevustevahelisi seoseid, et õppija arengut veelgi süsteemsemalt toetada. Ka ettevõtluse valdkonnas tehtud uuringutest ilmneb, et sageli esineb selliseid olukordi, kus enda pingutuse suunamine on teadlik tegevus, mis soodustab arengut ning aitab toime tulla keerukates ja emotsioonirohketes olukordades (Patzelt \& Shepherd, 2011). Edaspidi on oluline kirjeldada eelnimetatud alapädevuste (arenguuskumuste ja emotsioonidega toimetuleku) seoseid ka teiste enesejuhtimise valdkonna alapädevustega. Lisaks tuleks välja töötada parimad võimalikud mõõtevahendid teiste enesejuhtimise alapädevuste, nt metakognitsiooni, autonoomse motivatsiooni mõõtmiseks, sh ettevõtlusega seotult.

Uurimuse faktoranalüüsi tulemused näitasid, et väärtust loova mõtlemise valdkonna alapädevused (probleemilahendusoskus, planeerimine (mõõdetuna ajaplaneerimise kaudu), loovus ning väärtuspõhisus) eristuvad üksteisest. Alapädevustest on omavahel rohkem seotud loovus, probleemilahendus ja planeerimine, vähem väärtuspõhisus. Loovuse ja probleemilahenduse hindamiseks 
valitud väited kirjeldasid enam oskust oma tegevusi mõtestada (olles seotud töömälu ning mõtlemise paindlikkusega, vt Diamond, 2013) ning luua probleemsetes olukordades varasema info põhjal uusi seoseid (Dziedziewicz, Gajda, \& Karwowski, 2014). Planeerimist kirjeldati kui üht probleemilahenduse etappi, mis väljendub vajalike tegevuste läbimõtlemises (Collins \& Koechlin, 2012). Eeltoodut arvestades on ilmnenud alapädevustevahelised seosed ootuspärased. Eetilisuse ja väärtuspõhisuse seosed teiste alapädevustega ei ole märkimisväärsed, mis viitab, et selle alapädevuse hindamise vahend vajab täiendamist. Ettevõtluspädevuse mudeliga soovitakse rõhutada, et kõiki väärtust loova mõtlemise valdkonnas kirjeldatud alapädevusi saab arendada ning need nõuavad sügavat infotöötlust eeldavate mõtlemisprotsessidena eraldi tähelepanu ja aega.

Sotsiaalsete olukordade lahendamise pädevusvaldkonnas hinnati kolme alapädevust, milles eristusid neli faktorit: algatamine, sotsiaalne teadlikkus, suhete juhtimine ja koostöö. Väiksemate faktorlaadungite tõttu langes iga pädevuse väidete hulgast välja üks väide, mille tulemusena tugevnesid eelnimetatud alapädevuste (faktorite) seosed teiste alapädevustega. Sotsiaalsete olukordade lahendamise olulisust kinnitavad ka varasemad uurimused, milles hinnati ettevõtjate sotsiaalse pädevuse seotust ettevõtte edukusega (nt Baron \& Markman, 2003).

Äriideede elluviimise valdkonnas olid kõik alapädevused omavahel positiivselt seotud. Lisaks ilmnesid positiivsed seosed enamiku teiste alapädevustega vaid seos eetika ja väärtuspõhisuse alapädevusega ei olnud statistiliselt oluline. Samas tuli äriideede elluviimise valdkonnas mudelist välja jätta keskkonna mõistmise alapädevuse väited, mis olid ärivõimaluste avastamise ja finantskirjaoskuse alapädevustega negatiivselt seotud. Põhjuseks oli väidete sisu, mis ei eristanud selgelt indiviidi ja keskkonna suhteid ettevõtlusprotsessi kontekstis. Kuigi indiviidi ja keskkonna seosed kajastuvad ka ärivõimaluste avastamise alapädevuses, tuleb edaspidi katsetada uute väidetega, mida saab enesehindamise kaudu paremini hinnata, olles esitatud eraldi alapädevusena või lõimitud ärivõimaluste avastamise alapädevusse.

Kokkuvõtvalt saab väita, et empiirilise analüüsi tulemused võimaldavad korrigeerida mõne alapädevuse mõõtmise vahendeid. Keskkonna mõistmise ning eetilisuse ja värrtuspõhisuse alapädevuste kohta selgus, et hindamisvahendeid on vaja edasi arendada ning empiiriliselt uuesti hinnata. Ülejäänud hindamisvahendite väited koos täiendustega sobivad ettevõtluspädevuse hindamiseks koos ja eraldi (alapädevuste kaupa). Seega kinnitab empiiriline uurimus, et enamiku mudelisse valitud ja teoreetiliselt põhjendatud alapädevusi on omavahel seotud ning sobivad tervikmudeli loomiseks. Ettevõtluspädevuse mudel pakub usaldusväärset lähtekohta õppija ettevõtluspädevuse arendamiseks ja 
toetamiseks. Samuti annavad tulemused alust arvata, et mudeli põhjendatuse kinnitamiseks peab alapädevusi uurima pikema aja jooksul, võttes arvesse teisi taustategureid (nt aktiivsus eri tegevusvaldkondades, soov saada ettevõtjaks, ettevõtluskogemus, kaaslaste ja õpetajate hinnang ettevõtlusele).

\section{Kokkuvõte}

Uurimuse raames välja töötatud ettevõtluspädevuse mudeli eesmärk oli luua empiiriliselt põhjendatud alus ettevõtlusõppe arendamiseks kõigil haridustasemetel. Alapädevuste valikul ja mudeli väljatöötamisel toetuti ettevõtluse kui äriideede elluviimise protsessi teoreetilisele käsitusele ning ettevõtlusega seotud teadusvaldkondades, sh (arengu)psühholoogias, haridusteadustes, sotsiaalpsühholoogias loodud teoreetilistele ja kontseptuaalsetele raamistikele. Mudeli sisu avamine aitab selgitada põhimõtteid, mille alusel saab arendada ettevõtlusõpet ja kavandada ettevõtlikkuse kui ülekantava pädevuse lõimimist õppeainetesse.

Ettevõtluspädevuse mudeli struktuur väljendab tervikliku pädevusmudeli loogikat (vt nt Le Deist \& Winterton, 2005), mis sisaldab erialaseid pädevusi, st äriideede elluviimist, ja üld- või ülekantavaid pädevusi ehk ettevõtlikkust toetavaid pädevusi, mis on vajalikud nii tegutsemiseks ettevõtluses ja palgatööl kui ka igapäevaelus. Peamine erinevus Taani, Euroopa või Skandinaavia ettevõtluspädevuse mudelist (Bacigalupo et al., 2016; Rasmussen \& Fritzner, 2016; Rasmussen et al., 2015) on suurem rõhuasetus enesejuhtimisele, mis on eraldi valdkonnana esile toodud. Kõigis pädevusmudelites rõhutatakse sotsiaalsete pädevuste olulisust võimaluste avastamisel ja ideede elluviimisel. Ettevõtluspädevuse mudeli rakendamine võimaldab suunata õppe- ja ainekavade planeerimist, mis omakorda soodustab uute õppemeetodite rakendamist ning loob aluse ettevõtlikkuse ja ettevõtlusõppe süsteemseks arendamiseks üld-, kutse- ja kõrghariduses.

Väljatöötatud mudeli alusel koostati (enese)hindamisvahend, mis võimaldab hinnata õppija ettevõtluspädevust ja selle arengut ettevõtlusõppes, aga ka ettevõtlusõppe tulemuslikkust. Ettevõtluspädevuse mudeli ja nii õppes kui ka individuaalselt kasutatava enesehindamisvahendi väljatöötamine pakub võimalust arendada ettevõtlusõpet ja ettevõtlikkust toetavaid alapädevusi kõigil elualadel, olles rahvusvahelisel tasandil täienduseks teiste riikide mudelitele. Ettevõtluspädevuse enesehindamisvahendil põhinev ettevõtlusõppe tulemuslikkuse hindamine toetab pädevuspõhise õppe rakendamist, samuti saab enesehindamisvahendit kasutada õppevarana õppeprotsessis eri alapädevuste tundmaõppimisel ja nende teadlikul rakendamisel ettevõtlusprotsessi planeerimise faasis. 
Ettevõtluspädevuse mudelis sisalduvate alapädevuste valiku empiiriline põhjendamine, mille tarbeks kasutati kõrgkooliõppijate valimit, kinnitas enamiku mudelisse valitud alapädevuste sobivust ja nende omavahelist seotust mudeli kui tervikuga, kuid osutas ka vajadusele arendada enesehindamisvahendit edasi. Kõrgkooliõppijate enesehinnangul põhineva uuringu empiirilised tulemused näitasid, et õppijad võivad olla enda teadmistelt, oskustelt ja hoiakutelt eri tasemel, mis tingib vajaduse pöörata tähelepanu ettevõtluspädevuse tasakaalustatud arendamisele kõigil haridustasemetel. Teisisõnu, oluline on mõista, kuidas ja milles väljenduvad ettevõtlikkus ning ettevõtlusalased teadmised ja oskused eri vanuses õppijal. Kirjeldatud uurimistulemus näitab, kui tähtis on toetada alapädevuste arendamist nii ettevõtlusõppes kui ka teiste õppevaldkondade kaudu. Empiirilise uuringu tulemused on ettevõtluspädevuse mudeli arendamise seisukohalt vajalikud, sest need võimaldavad luua usaldusväärse aluse ettevõtlusõppe arendamiseks.

Ettevõtluspädevuse mudeli rakendamise võimalused pakuvad ka ainest kõigile õpetajatele ja õppejõududele erialaainete ümbermõtestamiseks ning õppijate tasakaalustatud arengu tagamiseks õppe- ja ainekavade kavandamisel. Ettevõtliku hoiaku kujundamist toetavad alapädevused (enesejuhtimine, väärtust loov mõtlemine ja lahenduste leidmine, sotsiaalsete olukordade lahendamine) aitavad óppijal oma pingutusi suunata ja aktiivselt tegutseda ning on eduka karjääri aluseks. Ettevõtlikkuse kujundamine vajab õpetajate ja õppejõudude järjepidevat hoolt ning tarku õppe- ja tagasisidemeetodeid kogu õppija haridustee jooksul (nii formaal- kui ka mitteformaalhariduses). Loodud mudel võimaldab haridustasemete ja -liikide kaupa kirjeldada alapädevusi ja õpiväljundeid, olles aluseks ettevõtlusõppe moodulite (ainete) kavade väljatöötamisele või õppeprotsesside kirjeldamisele üld- ja erialaõppes.

Kindlasti vajavad ettevõtluspädevuse mudeli rakendamise võimalused edasist uurimist ning praeguse uurimuse andmete pinnalt ei saa teha laiapõhjalisi järeldusi. Oluline on meeles pidada, et uuringus kasutati peamiselt enesehinnangulisi hindamisvahendeid, mille pinnalt saame teada, mida õppijad enda omaduste, oskuste ja teadmiste kohta arvavad, aga mitte seda, milline on õppijate tegelik tase. Samuti on edaspidi mõistlik püüda hinnata, kas mudelisse koondatud pädevuste komplekt tõepoolest ennustab ettevõtlikkust teistes kontekstides, nt pikiuuringu korral. Pädevustevaheliste seoste kirjeldamisel tuleb edaspidi varasemast enam arvestada ka õpikeskkonna mõju. Samuti on vaja põhjalikumalt uurida haridustasemetevahelisi seoseid õppijate ettevõtluspädevuse arenguga. Siinse uurimuse tulemused pakuvad head lähtekohta nii enesehindamisvahendi kui ka ettevõtluspädevuse mudeli edasiseks arendamiseks. Artiklis esitatud ettevõtluspädevuse mudel on loodud praeguste parimate teadmiste pinnalt ning see võib muutuda koos muutustega haridussüsteemis 
ja ühiskonnas. Artikliga panustatakse diskussiooni ettevõtluspädevuse mudeli üle ja toetatakse mudeli rakendusvõimaluste loomist Eesti haridussüsteemi tarbeks.

\section{Tänusõnad}

Uurimuse valmimist on toetanud Euroopa Liit Euroopa sotsiaalfondi kaudu, finantseerides Haridus- ja Teadusministeeriumi eestvedamisel elluviidud programmi „Ettevõtlikkuse ja ettevõtlusõppe süsteemne arendamine kõigil haridustasemetel“ („Edu ja tegu“).

\section{Kasutatud kirjandus}

Alvarez, S. A., \& Barney, J. B. (2010). Entrepreneurship and epistemology: The philosophical underpinnings of the study of entrepreneurial opportunities. Academy of Management Annals, 4(1), 557-583. https://doi.org/10.5465/19416520.2010.495521

Anderson-Butcher, D., Amorose, A. J., Lower, L. M., Riley, A., Gibson, A., \& Ruch, D. (2014). The case for the Perceived Social Competence Scale II. Research on Social Work Practice, 26(4), 419-428. https://doi.org/10.1177/1049731514557362

Ardichvili, A., Cardozo, R., \& Ray, S. (2003). A theory of entrepreneurial opportunity identification and development. Journal of Business Venturing, 18(1), 105-123. https://doi.org/10.1016/S0883-9026(01)00068-4

Bacigalupo, M., Kampylis, P., Punie, Y., \& van den Brande, G. (2016). EntreComp: The Entrepreneurship Competence Framework. Luxembourg: Publication Office of the European Union.

Baggen, Y., Kampen, J. K., Naia, A., Biemans, H. J. A., Lans, T., \& Mulder, M. (2018). Development and application of the Opportunity Identification Competence Assessment Test (OICAT) in higher education. Innovations in Education and Teaching International, 55(6), 735-745.

https://doi.org/10.1080/14703297.2017.1348962

Baker, D. P., Day, R., \& Salas, E. (2006). Teamwork as an essential component of highreliability organizations. Health Services Research, 41(4), 1576-1598. https://doi.org/10.1111/j.1475-6773.2006.00566.x

Baron, R. A., \& Ensley, M. D. (2006). Opportunity recognition as the detection of meaningful patterns: Evidence from comparisons of novice and experienced entrepreneurs. Management Science, 52(9), 1331-1344. https://doi.org/10.1287/mnsc. 1060.0538

Baron, R. A., \& Markman, G. D. (2003). Beyond social capital: The role of entrepreneurs' social competence in their financial success. Journal of Business Venturing, 18(1), 41-60. https://doi.org/10.1016/S0883-9026(00)00069-0

Bartram, D. (2005). The great eight competencies: A criterion-centric approach to validation. Journal of Applied Psychology, 90(6), 1185-1203.

https://doi.org/10.1037/0021-9010.90.6.1185 
Baum, J. R., \& Locke, E. A. (2004). The relationship of entrepreneurial traits, skill, and motivation to subsequent venture growth. Journal of Applied Psychology, 89(4), 587-598. https://doi.org/10.1037/0021-9010.89.4.587

Beauchamp, M. H., \& Anderson, V. (2010). SOCIAL: An integrative framework for the development of social skills. Psychological Bulletin, 136(1), 39-64. https://doi.org/10.1037/a0017768

Bennett, R. (2006). Business lecturers' perceptions of the nature of entrepreneurship. International Journal of Entrepreneurial Behavior and Research, 12(3), 165-188. https://doi.org/10.1108/13552550610667440

Bird, B. (1995). Towards a theory of entrepreneurial competency. In J. A. Katz \& R. H. Brockhaus (Eds.), Advances in entrepreneurship, firm emergence and growth (Vol. 2, pp. 51-72). Greenwich: JAI Press.

Blenker, P., Frederiksen, S. H., Korsgaard, S., Müller, S., Neergaard, H., \& Thrane, C. (2012). Entrepreneurship as everyday practice: Towards a personalized pedagogy of enterprise education. Industry and Higher Education, 26(6), 417-430. https://doi.org/10.5367/ihe.2012.0126

Blenker, P., Korsgaard, S., Neergaard, H., \& Thrane, C. (2011). The questions we care about: Paradigms and progressions in EE. Industry and Higher Education, 25(6), 417-427. https://doi.org/10.5367/ihe.2011.0065

Buil, M., Aznar, J. P., Galiana, J., \& Rocafort-Marco, A. (2016). An explanatory study of MBA students with regards to sustainability and ethics commitment. Sustainability, 8(3), 280. https://doi.org/10.3390/su8030280

Cheruvelil, K. S., Soranno, P. A., Weathers, K. C., Hanson, P. C., Gorning, S. J., ... \& Read, E. K. (2014). Creating and maintaining high-performing collaborative research teams: The importance of diversity and interpersonal skills. Frontiers in Ecology and the Environment, 12(1), 31-38. https://doi.org/10.1890/130001

Collins, A., \& Koechlin, E. (2012). Reasoning, learning, and creativity: Frontal lobe function and human decision-making. PLoS Biology, 10(3), e1001293. https://doi.org/10.1371/journal.pbio.1001293.

Cope, J. (2005). Toward a dynamic learning perspective of entrepreneurship. Entrepreneurship Theory and Practice, 29(4), 373-397. https://doi.org/10.1111/j.1540-6520.2005.00090.x

Corbett, A. C. (2005). Experiential learning within the process of opportunity identification and exploitation. Entrepreneurship Theory and Practice, 29(4), 473-491. https://doi.org/10.1111/j.1540-6520.2005.00094.x

Davidsson, P. (2015). Entrepreneurial opportunities and the entrepreneurship nexus: A re-conceptualization. Journal of Business Venturing, 30(5), 674-695. https://doi.org/10.1016/j.jbusvent.2015.01.002

Dawson, P., \& Guare, R. (2011). Executive skills in children and adolescents: A practical guide to assessment and intervention (2nd ed.). New York: The Guilford Press.

Deci, E. L., \& Ryan, R. M. (2000). The 'what' and 'why' of goal pursuits: Human needs and the self-determination of behavior. Psychological Inquiry, 11(4), 227-268. https://doi.org/10.1207/S15327965PLI1104_01

DeShon, R. P., \& Gillespie, J. Z. (2005). A motivated action theory account of goal orientation. Journal of Applied Psychology, 90(6), 1096-1127. https://doi.org/10.1037/0021-9010.90.6.1096 
DeTienne, D. R., \& Chandler, G. N. (2004). Opportunity identification and its role in the entrepreneurial classroom: A pedagogical approach and empirical test. Academy of Management Learning and Education, 3(3), 242-257. https://doi.org/10.5465/amle.2004.14242103

Diamond, A. (2013). Executive functions. Annual Review of Psychology, 64, 135-168. https://doi.org/10.1146/annurev-psych-113011-143750

Dimov, D. (2007). From opportunity insight to opportunity intention: The importance of person-situation learning match. Entrepreneurship Theory and Practice, 31(4), 561-583. https://doi.org/10.1111/j.1540-6520.2007.00188.x

Dziedziewicz, D., Gajda, A., \& Karwowski, M. (2014). Developing children's intercultural competence and creativity. Thinking Skills and Creativity, 13(1), 32-42. https://doi.org/10.1016/j.tsc.2014.02.006

Dube, S., \& Marnewick, C. (2015). A conceptual model to improve performance in virtual teams. South African Journal of Information Management, 18(1), 1-10.

Dweck, C. S. (2016, January 13). What having a "growth mindset" actually means. Harvard Business Review Web Article. Retrieved from https://hbr.org/2016/01/what-having-a-growth-mindset-actually-means.

Dweck, C. S., \& Leggett, E. L. (1988). A social-cognitive approach to motivation and personality. Psychological Review, 95(2), 256-273. https://doi.org/10.1037/0033-295X.95.2.256

Edu ja Tegu programm (2016). Ettevõtlikkuse ja ettevõtlusõppe süsteemne arendamine kõigil haridustasemetel. Euroopa sotsiaalfond. Külastatud aadressil https://ettevõtlusõpe.ee/index.php.

Efklides, A. (2011). Interactions of metacognition with motivation and affect in selfregulated learning: The MASRL model. Educational Psychologist, 46(1), 6-25. https://doi.org/10.1080/00461520.2011.538645

Efklides, A. (2014). How does metacognition contribute to the regulation of learning? An integrative approach. Psihologijske teme, 23(1), 1-30.

Ericsson, K. A., Krampe, R. T., \& Tesch-Römer, C. (1993). The role of deliberate practice in the acquisition of expert performance. Psychological Review, 100(3), 363406. https://doi.org/10.1037/0033-295X.100.3.363

European Commission (2006). Key competences for lifelong learning. Recommendation of the members of the European Parliament and the Council (2006/962/EC; 18 December). Brussels: Commission of the European Communities.

European Commission (2016). Entrepreneurship education at school in Europe. Eurydice Report. Luxembourg: Publications Office of the European Union.

Fayolle, A. (2013). Personal views on the future of entrepreneurship education. Entrepreneurship \& Regional Development: An International Journal, 25(7/8), 692-701. https://doi.org/10.1080/08985626.2013.821318

Fayolle, A., Gailly, B., \& Lassas-Clerc, N. (2006). Assessing the impact of entrepreneurship education programmes: A new methodology. Journal of European Industrial Training, 30(9), 701-720. https://doi.org/10.1108/03090590610715022

FFE-YE (2012). Impact of entrepreneurship education in Denmark - 2011. Odense: The Danish Foundation for Entrepreneurship - Young Enterprise. Retrieved from http://eng.ffe-ye.dk/media/202248/impact_of_entrepreneurship_education_in_ denmark_2011.pdf. 
Flavell, J. H. (1979). Metacognition and cognitive monitoring: A new area of cognitive-developmental inquiry. American Psychologist, 34(10), 906-911. https://doi.org/10.1037/0003-066X.34.10.906

Frese, M. (2009). Toward a psychology of entrepreneurship - An action theory perspective. Foundations and Trends in Entrepreneurship, 5(6), 435-494. https://doi.org/10.1561/0300000028

Frese, M., \& Fay, D. (2001). Personal initiative: An active performance concept for work in the 21st century. Research in Organizational Behavior, 23(1), 133-187. https://doi.org/10.1016/S0191-3085(01)23005-6

Garnefski, N., \& Kraaij, V. (2006). Cognitive Emotion Regulation Questionnaire Development of a short 18-item version (CERQ-short). Personality and Individual Differences, 41(6), 1045-1053. https://doi.org/10.1016/j.paid.2006.04.010

Gibb, A. (2008). Entrepreneurship and enterprise education in schools and colleges: Insights from UK practice. International Journal of Entrepreneurship Education, 6(2), 101-144.

Gibb, A. (2010). Concepts into practice: Meeting the challenge of development of entrepreneurship educators around an innovative paradigm. The case of the International Entrepreneurship Educators Programme (IEEP). International Journal of Entrepreneurship Behaviour \& Research, 17(2), 146-165. https://doi.org/10.1108/13552551111114914

Haridus- ja Teadusministeerium (2018). Eesti elukestva õppe strateegia 2020. Külastatud aadressil https://www.hm.ee/sites/default/files/strateegia2020.pdf.

Kapur, M. (2015). The preparatory effects of problem solving versus problem posing on learning from instruction. Learning and Instruction, 39(October), 23-31. https://doi.org/10.1016/j.learninstruc.2015.05.004

Karimi, S., Biemans, H. J. A., Lans, T., Aazami, M., \& Mulder, M. (2014). Fostering students competence in identifying business opportunities in entrepreneurship education. Innovations in Education and Teaching International, 53(2), 215-229. https://doi.org/10.1080/14703297.2014.993419

Karwowski, M. (2014). Creative mindsets: Measurement, correlates, consequences. Psychology of Aesthetics, Creativity, and the Arts, 8(1), 62-70. https://doi.org/10.1037/a0034898

Kelley, T., \& Littman, J. (2001). The art of innovation: Lessons in creativity from IDEO, America's leading design firm. New York etc.: Currency Books.

Kikas, E. (2015). Tunnetusprotsessid, uskumused, emotsioonid ja motivatsioon. Nende iseärasused ja arengu toetamine kolmandas kooliastmes. E. Kikas \& A. Toomela (toim.), Õppimine ja õpetamine kolmandas kooliastmes. Üldpädevused ja nende arendamine (lk 34-62). Tallinn: Eesti Ülikoolide Kirjastus.

Kjellberg, A., \& Haglund, L. (2016). Utilization of the Swedish version of the assessment of communication and interaction skills. British Journal of Occupational Therapy, 79(4), 228-234. https://doi.org/10.1177/0308022615580328

Kyndt, E., \& Baert, H. (2015). Entrepreneurial competencies: Assessment and predictive value for entrepreneurship. Journal of Vocational Behavior, 90 (October), 13-25. https://doi.org/10.1016/j.jvb.2015.07.002

Lackéus, M. (2015). Entrepreneurship in education: What, why, when, how. Background paper. Trento: OECD-LEED. 
Lans, T., Biemans, H., Mulder, M., \& Verstegen, J. (2010). Self-awareness of mastery and improvability of entrepreneurial competence in small businesses in the agrifood sector. Human Resource Development Quarterly, 21(2), 147-168. https://doi.org/10.1002/hrdq.20041

Lans, T., Blok, V., \& Gulikers, J. (2015). Show me your network and I'll tell you who you are: Social competence and social capital of early stage entrepreneurs. Entrepreneurship \& Regional Development, 27(7/8), 458-473. https://doi.org/10.1080/08985626.2015.1070537

Lans, T., Blok, V., \& Wesselink, R. (2014). Learning apart and together: Towards an integrated competence framework for sustainable entrepreneurship in higher education. Journal of Cleaner Production, 62(1), 37-47. https://doi.org/10.1016/j.jclepro.2013.03.036

Lans, T., Hulsink, W., Baert, H., \& Mulder, M. (2008). Entrepreneurship education and training in a small business context: Insights from the competence-based approach. Journal of Enterprising Culture, 16(4), 363-383. https://doi.org/10.1142/S0218495808000193

Le Deist, F., \& Winterton, J. (2005). What is competence? Human Resource Development International, 8(1), 27-46. https://doi.org/10.1080/1367886042000338227

Lilleväli, U., \& Täks, M. (2017). Competence models as a tool for conceptualizing the systematic process of entrepreneurship competence development. Education Research International. Retrieved from https://www.hindawi.com/journals/edri/2017/5160863/.

Lower, L. M., Newman, T. J., \& Anderson-Butcher, D. (2015). Validity and reliability of the teamwork scale for youth. Research on Social Work Practice, 27(6), 1-10.

Man, T. W. Y., Lau, T., \& Chan, K. F. (2002). The competitiveness of small and medium enterprises: A conceptualization with focus on entrepreneurial competencies. Journal of Business Venturing, 17(2), 123-142. https://doi.org/10.1016/S0883-9026(00)00058-6

Man, T. W. Y., Lau, T., \& Snape, E. (2008). Entrepreneurial competencies and the performance of small and medium enterprises: An investigation through a framework of competitiveness. Journal of Small Business \& Entrepreneurship, 21(3), 257-276. https://doi.org/10.1080/08276331.2008.10593424

McMullen, J. S., \& Dimov, D. (2013). Time and the entrepreneurial journey: The problems and promise of studying entrepreneurship as a process. Journal of Management Studies, 50(8), 1481-1512. https://doi.org/10.1111/joms.12049

Mitchell, J. R., Smith, J. B., Gustafsson, V., Davidsson, P., \& Mitchell, R. K. (2005). Thinking about thinking about thinking: Exploring how entrepreneurial metacognition affects entrepreneurial expertise. The Babson Research Conference June 10, 2005, Babson College, Wellesley, MA.

Morris, M. H., Webb, J. W., Fu, J., \& Singhal, J. (2013). A competency-based perspective on entrepreneurship education: Conceptual and empirical insights. Journal of Small Business Management, 51(3), 352-369. https://doi.org/10.1111/jsbm.12023

Mulder, M., Gulikers, J., Biemans, H., \& Wesselink, R. (2009). The new competence concept in higher education: Error or enrichment? Journal of European Industrial Training, 33(8/9), 755-770. https://doi.org/10.1108/03090590910993616

Mwasalwiba, E. S. (2010). Entrepreneurship education: A review of its objectives, teaching methods, and impact indicators. Education \& Training, 52(1), 20-47. https://doi.org/10.1108/00400911011017663 
National Standards of Practice for Entrepreneurship Education (2004). USA: The Consortium of Entrepreneurship Education.

Neck, H. M., \& Greene, P. G. (2011). Entrepreneurship education: Known worlds and new frontiers. Journal of Small Business Management, 49(1), 55-70. https://doi.org/10.1111/j.1540-627X.2010.00314.x

OECD (2016). Preparing our youth for an inclusive and sustainable world. The OECD PISA Global Competence Framework. Retrived from https://www.oecd.org/education/Global-competency-for-an-inclusive-world.pdf.

Patzelt, H., \& Shepherd, D. A. (2011). Recognizing opportunities for sustainable development. Entrepreneurship Theory and Practice, 35(4), 631-652. https://doi.org/10.1111/j.1540-6520.2010.00386.x

Pittaway, L., \& Cope, J. (2007). Entrepreneurship education: A systematic review of the evidence. International Small Business Journal, 25(5), 479-510. https://doi.org/10.1177/0266242607080656

Rasmussen, A., \& Fritzner, A. (2016). From dream to reality: Learning outcomes and didactic principles for teaching entrepreneurship in Nordic schools. Copenhagen: Nordic Council of Ministers. https://doi.org/10.6027/ANP2016-709

Rasmussen, A., Moberg, K., \& Revsbech, C. (2015). A taxonomy of entrepreneurship education: Perspectives on goals, teaching and evaluation. Odense: The Danish Foundation for Entrepreneurship - Young Enterprise.

Rasmussen, A., \& Nybye, N. (2013). Entrepreneurship education: Progression model. Odense: The Danish Foundation for Entrepreneurship - Young Enterprise.

Salas, E., Cooke, N. J., \& Rosen, M. A. (2008). On teams, teamwork, and team performance: Discoveries and developments. The Journal of the Human Factors and Ergonomics Society, 50(3), 540-547. https://doi.org/10.1518/001872008X288457

Sarasvathy, S. D., \& Venkataraman, S. (2011). Entrepreneurship as method: Open questions for an entrepreneurial future. Entrepreneurship Theory and Practice, 35(1), 113-135. https://doi.org/10.1111/j.1540-6520.2010.00425.x

Scott, G., Leritz, E. L., \& Mumford, M. D. (2004). The effectiveness of creativity training: A quantitative review. Creativity Research Journal, 16(4), 361-388. https://doi.org/10.1080/10400410409534549

Sawyer, R. K. (2012). Explaining creativity: The science of human innovation (2nd ed.). New York: Oxford University Press.

Schindehutte, M., Morris, M., \& Allen, J. (2006). Beyond achievement: Entrepreneurship as extreme experience. Small Business Economics, 27(4/5), 349-368. https://doi.org/10.1007/s11187-005-0643-6

Shane, S. (2003). A general theory of entrepreneurship: The individual-opportunity nexus. Cheltenham: Edward Elgar. https://doi.org/10.4337/9781781007990

Shane, S., \& Venkataraman, S. (2000). The promise of entrepreneurship as a field of research. The Academy of Management Review, 25(1), 217-226. https://doi.org/10.5465/amr.2000.2791611

Sternberg, R. J. (2006). The nature of creativity. Creativity Research Journal, 18(1), 87-98. https://doi.org/10.1207/s15326934crj1801_10

Steyaert, C., \& Katz, J. (2004). Reclaiming the space of entrepreneurship in society: Geographical, discursive and social dimensions. Entrepreneurship and Regional Development, 16(3), 179-196. https://doi.org/10.1080/0898562042000197135 
Zhou, M., \& Ee, J. (2012). Development and validation of the Social Emotional Competence Questionnaire (SECQ). The International Journal of Emotional Education, 4(2), 27-42.

Tang, J., Kacmar, K. M. M., \& Busenitz, L. (2012). Entrepreneurial alertness in the pursuit of new opportunities. Journal of Business Venturing, 27(1), 77-94. https://doi.org/10.1016/j.jbusvent.2010.07.001

Toomela, A. (2003). Development of symbol meaning and the emergence of the semiotically mediated mind. In A. Toomela (Ed.), Cultural guidance in the development of the human mind (pp. 163-209). Westport: Ablex Publishing.

Ucbasaran, D., Westhead, P., \& Wright, M. (2008). Opportunity identification and pursuit: Does an entrepreneur's human capital matter? Small Business Economics, 30(2), 153-173. https://doi.org/10.1007/s11187-006-9020-3

Van der Laan, R., Driessen, M., \& Zwart, P. (2010). Entrepreneur scan identifies potential fast growers. Retrieved from http://www.ondernemerstest.nl/wp-content/ uploads/2011/04/Entrepreneur-Scan-identifies-potential-fast-growers-v6.pdf.

Wesselink, R., \& Wals, A. E. J. (2011). Developing competence profiles for educators in environmental education organisations in the Netherlands. Environmental Education Research, 17(1), 69-90. https://doi.org/10.1080/13504621003637037

Winterton, J. (2002). Entrepreneurship: Towards a competence framework for developing SME managers. United States Association for Small Business and Entrepreneurship, Conference Proceedings. Reno, Nevada.

Yeager, D. S., \& Dweck, C. S. (2012). Mindsets that promote resilience: When students believe that personal characteristics can be developed. Educational Psychologist, 47(4), 302-314. https://doi.org/10.1080/00461520.2012.722805 


\title{
Model of entrepreneurship competence as a basis for the development of entrepreneurship education
}

\author{
Urve Venesaar ${ }^{\mathrm{a} 1}$, Marge Täks ${ }^{\mathrm{bc}}$, Grete Arro ${ }^{\mathrm{d}}$, Elina Malleus ${ }^{\mathrm{de}}$, \\ Krista Loogma ${ }^{d}$, Kaja Mädamürkd, Eneken Titov ${ }^{\mathrm{f}}$, Martin Todinga \\ ${ }^{a}$ Department of Business Administration, Tallinn University of Technology \\ ${ }^{b}$ School of Economics and Business Administration, University of Tartu \\ ${ }^{c}$ Estonian Business School \\ ${ }^{d}$ School of Educational Sciences, Tallinn University \\ ${ }^{e}$ School of Natural Sciences and Health, Tallinn University \\ ${ }^{f}$ Estonian Entrepreneurship University of Applied Sciences
}

\section{Summary}

In the last decades, the focal point of entrepreneurship education (EE) research has been developing a better understanding of the competencies related to entrepreneurship competence (e.g. Cope, 2005; Neck \& Greene, 2011; Sarasvathy \& Venkataraman, 2011). Moving toward competency-based education and entrepreneurship competence development provides opportunities to see EE broader than learning for creating new businesses. Also, several researchers have started to make a distinction between "narrow" and "broad" approach to entrepreneurship (Gibb, 2010; Lackéus, 2015, and others). The narrow approach to entrepreneurship is understood as the creation and development of new businesses, and the broad approach to entrepreneurship is seen as the day-to-day activity of creating value in society (Blenker et al., 2012). Adopting the broad approach means creating entrepreneurial mindsets and active citizens. Developing learners' entrepreneurial mindsets requires learning processes that support active, experiential learning and fosters the development of entrepreneurship competencies. Broad, competency-based approach, in turn, allows seeing entrepreneurship education from two different points of views: 1) as a discipline (e.g., offering a separate course), or 2) as a method (e.g., as a teaching approach, embedding entrepreneurship education into the curriculum) (Blenker et al., 2011; Fayolle, 2013).

According to previous studies, entrepreneurship has been taught very differently (Fayolle et al., 2006). Latter is grounded on the lack of consensus on the

Department of Business Administration, Tallinn University of Technology, Akateemia tee 3, 12618 Tallinn, Estonia; urve.venesaar@ttu.ee 
fundamental concepts "entrepreneurship", "enterprise" and "entrepreneurial" (Mwasalwiba, 2010) and how entrepreneurship should be taught (Bennett, 2006). This situation has created confusion in the organisation of entrepreneurship courses and training (Pittaway \& Cope, 2007) in setting learning goals, formulating learning outcomes, and using learning assessment methods (Mwasalwiba, 2010).

Historically, in Estonia, entrepreneurship courses followed the principles of the narrow approach, meaning that courses mainly aimed at supporting the creation of new businesses. Recently, the implementation of the broad concept of EE has become more important, i.e. embedding entrepreneurship education into the curricula and to the general and speciality courses. Adopting the broad approach earlier was complicated due to different definition and theories for designing the courses, and lack of a consistent framework that would highlight how EE should be approached throughout the educational levels. To address this gap, the Estonian Ministry of Education and Research launched the programme "Systemic Development of Entrepreneurship and Entrepreneurship at All Educational Levels" (Edu ja Tegu ..., 2016). Following the previous line of thought, this article aims to highlight and justify the entrepreneurship competence model designed for the developments of entrepreneurship education in Estonia throughout the educational levels. Based on this aim we set the following research questions: 1) What competencies are needed to implement ideas to create value in different environments? 2) How to validate selected sub-competencies empirically?

The entrepreneurship competence and its sub-competencies are developed on the basis a definition: "Entrepreneurship is when you act upon opportunities and ideas and transform them into value for others. The value that is created can be financial, cultural, or social." (FFE-YE, 2012). The development of an entrepreneurship competence model is based on understanding the entrepreneurship process, and what competencies are needed in different phases of this process for the opportunity, discovery and implementation of ideas to find new and value-generating solutions. Ardichvili and colleagues (2003) claim that identifying opportunities for new business is one of the most important abilities of a successful entrepreneur. However, for identifying opportunities, also transferable competencies are necessary, namely, creative thinking, problem-solving, planning, communication and teamwork skills, self-management, and more. For explaining the content and mutual relationships of chosen sub-competencies for the entrepreneurship competence model, the theories from fields related to entrepreneurship (e.g., psychology, education, entrepreneurship) were used as the theoretical basis, and, at the same time, we took into account the laws of human thinking and general development and functioning. 
In the process of designing the entrepreneurship competence model, we also developed the assessment tool for measuring the competencies. The assessment is based on the adopted constructs from earlier studies as well as on the supplemented statements characterising the sub-competences of the model.

The structure of the entrepreneurship competence is presented to emphasise the way sub-competencies are interconnected. The sub-competencies are divided into four competence areas, namely - 1) self-management, 2) solving of social situations, 3) creative thinking and finding solutions, and 4) acting on opportunities, all together into 14 sub-competencies. Three prior competence areas are highlighting competencies needed for developing entrepreneurial mindsets, creative and entrepreneurial members of society. The fourth competence area - acting on opportunities - is necessary for entrepreneurial action and becoming an entrepreneur. Also, it is beneficial and essential for those choosing a career as an employee. The fourth competence area should be developed together with entrepreneurship sub-competencies of the other three competence areas.

The empirical study conducted, consisting of a sample numbering 1,479 higher education students, aged $16-66(M=26 ; S D=8.06)$. Based on the study a statistical basis for the interconnectedness of various entrepreneurship subcompetencies was established. The result of the study highlighted that the relationships between assessed competencies are logical and confirmed the results of previous research on different sub-competencies that were assessed. The self-assessment analysis confirmed that most of the sub-competencies' relations were anticipated correctly and at the same time, they were also separately significant. Only two sub-competencies, namely, 1) understanding the context, and 2) ethics and values, appeared to be not related with other sub-competencies and indicated the need to correct or rearrange the instrument accordingly.

The development of entrepreneurship competence model and the constructed self-assessment tool offers internationally - in addition to other countries' entrepreneurship competence models - a new solution for the development of entrepreneurial mindset and entrepreneurship competencies that are needed in all areas of life. Establishing the entrepreneurship competence model and related assessment tool is the first stage in the ministry-initiated EE programme. The competence model can be used as a basis for formulating learning outcomes for all educational levels, as well as planning the programmes for entrepreneurship courses (based on established outcomes) and developing pedagogical tools and instructions.

The implementation of competence-based learning into practice based on entrepreneurship competence model is an essential for various stakeholders within the education system (e.g. education authorities, curricula developers, 
teachers and lecturers, students, etc.). The results provide the basis for the systematisation, visualisation, and application of expertise relating to how, when, and which entrepreneurship sub-competencies should be developed as part of a particular education programme. Indeed, the feasibility of the applied entrepreneurship competence model needs to be investigated further, and farreaching conclusions cannot be drawn based only on the data from the current study.

The competence model's applicability validation is a long-term process. However, this study allows proposing the initial description of the entrepreneurship competence model. Further, while describing the relationship between competences, the effects of the learning environment must be emphasised more in the future research. The entrepreneurship competence model presented in this article is designed based on considering both the previous and recent scientific literature, and it may change together with the developments in the education system and society. This article contributes to the discussion on the use of the entrepreneurship competence model for the development of entrepreneurship education at all levels of education in Estonia.

Keywords: entrepreneurship education, model of entrepreneurship competence, acting upon opportunities, self-management, creative thinking and finding solutions, solving social situations 